\title{
Solubilities of Significant Organic Compounds in HLW Tank Supernate Solutions - FY 1996 Progress Report
}

G. S. Barney

Date Published

September 1996

Prepared for the U.S. Department of Energy Assistant Secretary for Environmental Management

$\begin{array}{ll}\text { Westinghouse } & \text { P.O Box } 1970 \\ \text { Hanford Company } & \text { Richland, Washington }\end{array}$

Management and Operations Contractor for the

U.S. Department of Energy under Contract DE-AC06-87RL10930

Approved for public release; distribution is unlimited 


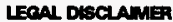

This report wes prepared es an acoount of work eponeored by an aganoy of the United States Government. Neither the Unitad States Govermment nor any conoy thareof, nor any of their employess, nor eny of their contrectors, subcontractors or their emplowees, makes any warranty, exprese or implied, or eacumes ony leged liebility or responsibility for the accuracy, completeneas, or any third party's use or the results of awh ues of eny information, epperatus, product, or process diectowed, or represente thet its use would not infiringe privately owned rights. Raference harein to any epecific commerciel product, prooeses, or evrvice by trede neme. trademark, manufecturer, or otharwise, does not necessarily conetitute or imply its endorement, recommendation, or fevoring by the United States Government or any eqency thereof or its contractors or abeontractors. The views and opinions of wuthore expresed herein do not necessarily state or reflect those of the United States Govermment or any egency thoreof.

This report hes been reproduced from the beet eveileble copy. Aveilable in pepar copy and microfiche.

Aveilable to the U.S. Department of Enorgy and its contrectors from

U.S. Department of Energy

Office of Scientific end Technicel Information (OST)

P.O. Eox 62

Oek Ridge, TN 37831

(615) 576-8401

Aveileble to the public from the U.S. Department of Commerce Netional Technicel infomation Sarvica (NTS)

5285 Port Royel Roed

Springfield, VA 22161

(703) $487-4650$

Primied in the Unind Sture of Ameries

DISCLM-1.CHP (8-95) 


\section{RELEASE AUTHORIZATION}

Document Number: WHC-EP-0899-1

Document Title: Solubility of Significant Organic Compounds in HLW Tank Supernate Solutions - FY 1996 Progress Report

Release Date: $\quad 9 / 30 / 96$

This document was reviewed following the procedures described in WHC-CM-3-4 and is: APPROVED FOR PUBLIC RELEASE

WHC Information Release Administration Specialist:

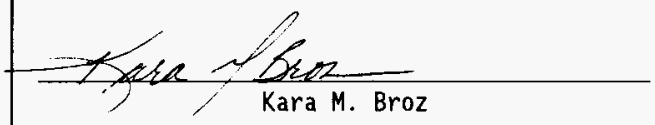


THIS PACE TNTENTIONALLY 1..TT BLANK 
WHC-EP-0899-1

\title{
THE SOLUBLITIES OF SIGNIFICANT ORGANIC COMPOUNDS IN HLW TANK SUPERNATE SOLUTIONS - FY1996 PROGRESS REPORT
}

\author{
G. S. Barney
}

\section{ABSTRACT}

The solubilities of two sodium salts of organic acids that are thought to exist in high-level waste at the Hanford Site were measured in tank supernate simulant solutions during FY1996. This solubility information will be used to determine if these organic salts could exist in solid phases (saltcake or sludges) in the waste where they might react violently with the nitrate or nitrite salts present in the tanks. Solubilities of sodium butyrate and trisodium N-(2-hydroxyethyl)ethylenediaminetriacetate were measured in simulated waste supernate solutions at $25^{\circ} \mathrm{C}, 30^{\circ} \mathrm{C}, 40^{\circ} \mathrm{C}$, and $50^{\circ} \mathrm{C}$. The organic compounds were selected because they are expected to exist in relatively high concentrations in the tanks. Two types of tank supernate simulants were used - a $4.0 \mathrm{M}$ sodium nitrate $-0.97 \mathrm{M}$ sodium nitrite solution with sodium hydroxide concentrations ranging from $0.00003 \mathrm{M}$ to $2.0 \mathrm{M}$ and a $2.0 \mathrm{M}$ sadium nitrite solution saturated with crystalline sodium nitrate with sodium hydroxide concentrations ranging from 0.1 $M$ to 2.0 M. The solubilities of sodium butyrate and trisodium $N$-(2-hydroxyethyl)ethylenediaminetriacetate in both types of HLW tank supernate solutions were high over the temperature and sodium hydroxide concentration ranges expected in the tanks. The solubilities of these compounds are similar (in terms of total organic carbon) to sodium glycolate, succinate, caproate, dibutylphosphate, citrate, formate, ethylenediaminetetraacetate, and nitrilotriacetate which were measured previously. High solubilities will prevent solid sodium salts of these organic acids from precipitating from tank supernate solutions. The total organic carbon concentrations (TOC) of actual tank supernates are generally much lower than the TOC ranges for the simulated supernate solutions saturated (at the solubility limit) with the organic salts. This 


\section{WHC-EP-0899-1}

is true even if all the dissolved carbon in a given tank supernate is due to only one of these eight soluble compounds (an unlikely situation). Solubilities of all the organic salts decrease with increasing sodium hydroxide and sodium nitrate concentration becouse of the common ion effect of $\mathrm{Na}^{+}$. Increasing temperatures has little effect on the solubilities of sadium butyrate and trisodium N-(2-hydroxyethyl)ethylenediaminetriacetate. 


\section{CONTENTS}

1.0 INTRODUCTION

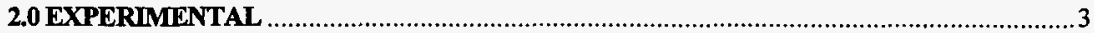

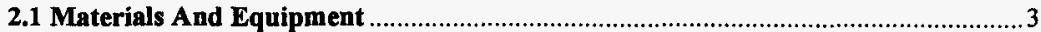

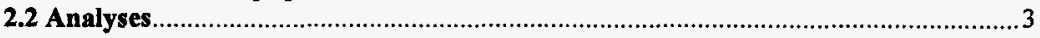

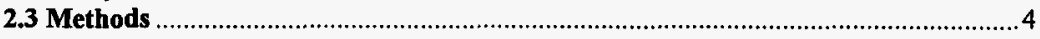

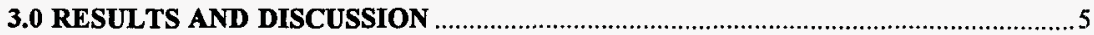

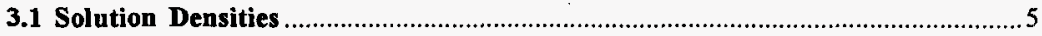

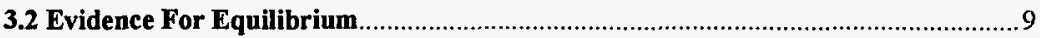

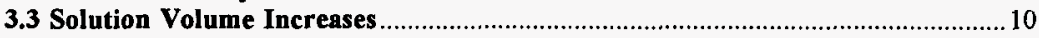

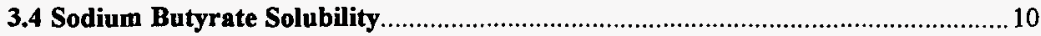

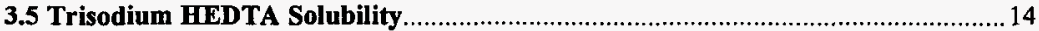

3.6 HLW Tank Total Organic Carbon Values ................................................. 18

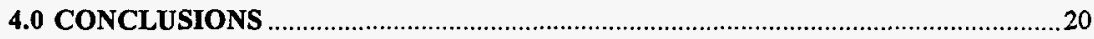

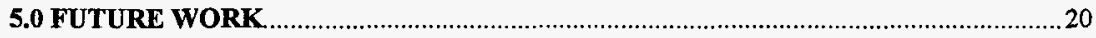

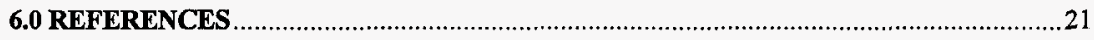

APPENDIX A - Solubilities of Organic Salts and Solution Compositions .....................A-1

APPENDIX B - Densities of Simulated Supernate Solutions Saturated with Organic Salts and Crystalline Sodium Nitrate ............................................... 
THIS PAGE INTENTIONALLY LETT BLANK 
WHC-EP-0899-1

\section{LIST OF FIGURES}

Figure 3-1 Densities of simulated supernate solutions saturated with crystalline $\mathrm{NaNO}_{3}$ and crystalline sodium HEDTA (A), glycolate (B), formate (C), and EDTA (D) at $25^{\circ} \mathrm{C}$, $30^{\circ} \mathrm{C}, 40^{\circ} \mathrm{C}$, and $50^{\circ} \mathrm{C}$ for various initial sodium hydroxide concentrations ..6

Figure 3-2 Densities of simulated supernate solutions saturated with crystalline $\mathrm{NaNO}_{3}$ and crystalline sodium citrate (A), caproate (B), butyrate (C), and acetate (D) at $25^{\circ} \mathrm{C}$, $30^{\circ} \mathrm{C}, 40^{\circ} \mathrm{C}$, and $50^{\circ} \mathrm{C}$ for various initial sodium hydroxide concentrations

Figure 3-3 Densities of simulated supernate solutions saturated with crystalline $\mathrm{NaNO}_{3}$ and crystalline sodium palmitate (A), oxalate (B), laurate (C), and NTA (D) at $25^{\circ} \mathrm{C}, 30$ ${ }^{\circ} \mathrm{C}, 40^{\circ} \mathrm{C}$, and $50^{\circ} \mathrm{C}$ for various initial sodium hydroxide concentrations

Figure 3-4 Densities of simulated supernate solutions saturated with crystalline $\mathrm{NaNO}_{3}$ and crystalline sodium succinate at $25^{\circ} \mathrm{C}, 30^{\circ} \mathrm{C}, 40^{\circ} \mathrm{C}$, and $50^{\circ} \mathrm{C}$ for various initial sodium hydroxide concentrations.

Figure 3-5 Solubility of sodium butyrate in $\mathrm{NaNO}_{3}-\mathrm{NaNO}_{2}$ solutions at $25^{\circ} \mathrm{C}, 30^{\circ} \mathrm{C}, 40^{\circ} \mathrm{C}$, and $50^{\circ} \mathrm{C}$ for various sodium hydroxide concentrations (A), and measured sodium nitrate concentrations in the same solutions (B).

Figure 3-6 Measured sodium nitrite concentrations in solutions where the solubility of sodium butyrate was determined in $\mathrm{NaNO}_{3}-\mathrm{NaNO}_{2}$ solutions at $25^{\circ} \mathrm{C}, 30^{\circ} \mathrm{C}, 40^{\circ} \mathrm{C}$, and $50^{\circ} \mathrm{C}$ and sodium hydroxide concentrations varied.

Figure 3-7 Solubility of sodium butyrate in $\mathrm{NaNO}_{3}-\mathrm{NaNO}_{2}$ solutions saturated with crystalline $\mathrm{NaNO}_{3}$ at $25^{\circ} \mathrm{C}, 30^{\circ} \mathrm{C}, 40^{\circ} \mathrm{C}$, and $50^{\circ} \mathrm{C}$ for various sodium hydroxide concentrations (A), and measured sodium nitrate concentrations in the same solutions (B).

Figure 3-8 Measured sodium nitrite concentrations in solutions where the solubility of sodium butyrate was determined. These solutions were saturated with crystalline $\mathrm{NaNO}_{3}$ at $25^{\circ} \mathrm{C}, 30^{\circ} \mathrm{C}, 40^{\circ} \mathrm{C}$, and $50^{\circ} \mathrm{C}$, the initial sodium nitrite concentration was $2.0 \mathrm{M}$, and initial sodium hydroxide concentrations varied from $0.1 \mathrm{M}$ to $2.0 \mathrm{M}$.

Figure 3-9 Solubility of sodium HEDTA in $\mathrm{NaNO}_{3}-\mathrm{NaNO}_{2}$ solutions at $25^{\circ} \mathrm{C}, 30^{\circ} \mathrm{C}, 40^{\circ} \mathrm{C}$, and $50^{\circ} \mathrm{C}$ for various sodium hydroxide concentrations (A), and measured sodium nitrate concentrations in the same solutions (B).

Figure 3-10 Measured sodium nitrite concentrations in solutions used above for sodium HEDTA solubility measurements at $25^{\circ} \mathrm{C}, 30^{\circ} \mathrm{C}, 40^{\circ} \mathrm{C}$, and $50^{\circ} \mathrm{C}$ and for various sodium hydroxide concentrations 
WHC-EP-0899-1

\section{LIST OF FIGURES (Cont.)}

Figure 3-11 Solubility of sodium HEDTA in $\mathrm{NaNO}_{3}-\mathrm{NaNO}_{2}$ solutions saturated with crystalline $\mathrm{NaNO}_{3}$ at $25^{\circ} \mathrm{C}, 30^{\circ} \mathrm{C}, 40^{\circ} \mathrm{C}$, and $50^{\circ} \mathrm{C}$ for various sodium hydroxide concentrations (A), and measured sodium nitrate concentrations in the same solutions (B).

Figure 3-12 Measured sodium nitrite concentrations in solutions where the solubility of sodium HEDTA was determined. These solutions were saturated with crystalline $\mathrm{NaNO}_{3}$ at $25^{\circ} \mathrm{C}, 30^{\circ} \mathrm{C}, 40^{\circ} \mathrm{C}$, and $50^{\circ} \mathrm{C}$, the initial sodium nitrite concentration was 2.0 $\mathrm{M}$, and initial sodium hydroxide concentrations varied from $0.1 \mathrm{M}$ to $2.0 \mathrm{M} . . . . . .18$

Figure 3-13 Frequency distribution of total organic carbon (TOC) concentrations measured in supernate solutions in 61 different Hanford Site HLW tanks. 


\section{WHC-EP-0899-1}

\section{LIST OF TABLES}

Table 1-1 Solubilities of organic sodium salts found in the literature 3

Table 3-1 Densities of the simulated supernate solutions and supernate solutions saturated with organic salts at $25^{\circ} \mathrm{C}$ to $50^{\circ} \mathrm{C}$ 5

Table 3-2 Average concentrations of organics versus time over all sodium hydroxide concentrations

Table 3-3 Volume increases due to dissolution of organic salts. 10

Table 3-4 Comparison of measured organic sodium salt solubilities in units of molarity and total organic carbon concentrations 


\section{ACRONYMS AND TERMS}

\begin{tabular}{|c|c|}
\hline DBP & dibutyl phosphate \\
\hline DSS & double-shell slurry \\
\hline EDTA & ethylenediaminetetraacetate \\
\hline ED3A & ethylenediaminetriacetate \\
\hline HDBP & dibutyl phosphoric acid \\
\hline HEDTA & $\mathrm{N}$-(2-hydroxyethyl)ethylenediaminetriacetate \\
\hline HLW & high-level waste \\
\hline IDA & iminodiacetate \\
\hline NTA & nitrilotriacetate \\
\hline TBP & tributyl phosphate \\
\hline TOC & total organic carbon \\
\hline NPH & normal parrafin hydrocarbon \\
\hline NCRW & neutralized cladding removal waste \\
\hline
\end{tabular}




\title{
THE SOLUBILITIES OF SIGNIFICANT ORGANIC COMPOUNDS IN HLW TANK SUPERNATE SOLUTIONS - FY1996 PROGRESS REPORT
}

\author{
G. S. Barney
}

\subsection{INTRODUCTION}

This report is a summary of work completed in FY1996 on the measurement of solubilities of organic compounds found in high-level waste (HLW) supernate solutions at Hanford. Earlier reports (Barney 1994 and 1995) presented the solubilities of nine sodium salts of organic acids that are known to exist in the wastes [sodium oxalate, formate, citrate, ethylenediaminetetraacetate (EDTA), nitrilotriacetate (NTA), glycolate, succinate, caproate, and dibutyl phosphate]. Solubilities of aluminum oxalate and iron and aluminum dibutyl phosphate compounds were also measured in simulated supernate solutions. The present document reports laboratory solubility measurements for additional compounds known or thought to exist in the wastes. These compounds are sodium butyrate and trisodium N-(2-hydroxyethyl)ethylenediaminetriacetate (HEDTA). Solubility measurements for additional compounds (sodium acetate, laurate, palmitate, and iminodiacetate) are in various stages of completion and will be documented later. Additional solubility measurements in simulated supernate solutions that are saturated with sodium nitrate (in addition to being saturated with the organic salt) are being completed for all these compounds.

The overall objective for these solubility measurements is to obtain solubility data that will allow prediction of whether or not significant quantities of organics exist as solids in the HLW tanks. Knowledge of which phase (liquid or solid) the organic compounds are in is important to safety analyses of the waste tanks and also to operations where the phases are separated (salt well pumping, evaporation-crystallization, etc.). These data will also allow better estimates of how organic compounds in the wastes were distributed to different tanks after transfer operations.

The safety concern for tanks containing high concentrations of organic compounds is that the organics might react violently with nitrate or nitrite salts, which are also present in the tanks, to produce heat and pressure from gaseous reaction products. The organic compounds and oxidizing salts must be present mainly in a solid form and the organic compounds must be present in a minimum concentration for a hazardous, self-propagating reaction to occur. The preliminary safety criteria (Webb et al. 1995) indicate that any waste organic-nitrite/nitrate mixture containing water concentrations greater than $20 \%$ by weight is safe and will not propagate. At or below this water concentration, the organic compounds in the waste must be present mainly as solids at the minimum total organic carbon (TOC) concentration range $(4.5 \%$ to $7.9 \%$ by weight, depending on water content) that allows propagating reactions. The solubilities of the organic compounds in the waste supernate solutions must therefore be exceeded to have a propagating mixture present in the waste. If the organic solubilities are known and are compared with concentrations found in the waste supernate solutions, the presence of solid organic compounds can be predicted. 
Prior measurements of the solubilities of sodium salts of formic acid, citric acid, EDTA, NTA, glycolic acid, succinic acid, caproic acid, and dibutyl phosphoric acid (Bamey 1994 and 1995) show that they are quite soluble in simulated supernate solutions. Their solubilities are much higher than any known TOC measurements of actual waste tank supernate solutions. This observation leads to the conclusion that none of these salts exist as solids in the tanks and that they will not form a propagating mixture. This, of course, assumes that the tank supernates analyzed are in equilibrium with the solid waste mixtures. Sodium oxalate solubilities were found to be relatively low and this compound could precipitate from some tank supernate solutions. The energy content of sodium oxalate is small, however.

Analyses of the organic components of several high-level wastes from different Hanford Site tanks have identified significant compounds. Campbell et al. $(1994,1995)$ analyzed core segments from tanks 241-SY-101 and 241-SY-103 and found the major organic components to be salts of chelating agents and low molecular weight carboxylic acids. The major chelating compounds were EDTA, NTA, citric acid, iminodiacetic acid (IDA), succinic acid, and ethylenediaminetriacetic acid (ED3A). The major low molecular weight carboxylic acids were oxalic, formic, glycolic, and acetic acids. Toste et al. (1988) identified organic compounds in a neutralized cladding removal waste (NCRW) and a double-shell slurry waste (DSS). They found citric acid, EDTA, tributyl phosphate, long chain hydrocarbons, and long chain carboxylic acids to be the major compounds present. Work at Georgia Institute of Technology (Ashby et al. 1994) and the Pacific Northwest National Laboratory (Camaioni et al. 1995) on waste tank simulants and actual wastes suggest that complexants in the tank wastes degrade by carbonnitrogen bond scission followed by oxidation of the reactive intermediates to carboxylic acids. Ultimately, oxalate, formate and carbonate are produced.

HEDTA has been identified in Tank 241-SY-103 waste by Campbell et al.(1995) even though it has been shown to slowly react under conditions expected in tank supernate solutions to form ethylenediaminetriacetate and oxalate (Delegard 1987). The sodium salt of butyric acid has not been identified in wastes, but is a possible oxidation product of tributyl phosphate which was added to the tanks in large quantities. Another possible source of butyrate is from degradation of the normal paraffin hydrocarbon (NPH) solvent used in the PUREX Process (Babad et al. 1993). The solubilities of these compounds were measured in simulated HLW supernate solutions containing sodium nitrate, sodium nitrite, and sodium hydroxide, which are major components of the HLW. Two simulant solutions were used: (1) a solution with initial concentrations of $4.0 \mathrm{M}$ sodium nitrate, $0.97 \mathrm{M}$ sodium nitrite, and sodium hydroxide concentrations ranging from $0.00003 \mathrm{M}$ to $2.0 \mathrm{M}$, and (2) a $2.0 \mathrm{M}$ sodium nitrite solution saturated with crystalline sodium nitrate and sodium hydroxide concentrations ranging form 0.1 $\mathrm{M}$ to $2.0 \mathrm{M}$. Temperatures during solubility measurements were controlled to $\pm 0.1^{\circ} \mathrm{C}$ over the range of $25^{\circ} \mathrm{C}$ to $50^{\circ} \mathrm{C}$. These values approximate conditions expected in the tanks so that the solubility data can be used to estimate solubilities in the actual wastes.

The solubilities of the sodium salts of butyric acid and HEDTA in sodium hydroxide solutions and in pure water, respectively, have been reported. These solubility data were used as starting points for designing the solubility measurements. The available literature data are summarized in Table 1-1. According to Bury and Owens (1935), the solid phases of sodium 
Table 1-1. Solubilities of organic sodium salts found in the literature.

\begin{tabular}{|c|c|c|c|c|}
\hline Compound Formula & Compound Name & $\begin{array}{l}\text { Solution } \\
\text { Composition }\end{array}$ & Observations & References \\
\hline $\mathrm{NaC}_{4} \mathrm{H}_{7} \mathrm{O}_{2}$ & Sodium Butyrate & $\begin{array}{l}\text { Sodium } \\
\text { Hydroxide } \\
\text { Solution }\end{array}$ & $\begin{array}{l}\text { Solubility at } 25^{\circ} \mathrm{C} \text { ranges } \\
\text { from about } 10.4 \mathrm{M} \text { in } 3.7 \mathrm{M} \\
\mathrm{NaOH} \text { to } 0.1 \mathrm{M} \text { in } 10 \mathrm{M} \\
\mathrm{NaOH}\end{array}$ & $\begin{array}{l}\text { Bury and Owens, } \\
1935\end{array}$ \\
\hline $\begin{array}{l}\mathrm{Na}_{3} \mathrm{C}_{10} \mathrm{H}_{15} \mathrm{~N}_{2} \mathrm{O}_{7} \\
2 \mathrm{H}_{2} \mathrm{O}\end{array}$ & $\begin{array}{l}\text { Trisodium } \\
\text { N-(2-Hydroxy- } \\
\text { ethylenediamine } \\
\text { triacetate }\end{array}$ & Water & $\begin{array}{l}\text { Solubility at } 25{ }^{\circ} \mathrm{C} \text { least } 41 \% \\
\text { by weight (about } 1.6 \mathrm{M} \text { ) }\end{array}$ & Versene* literature \\
\hline
\end{tabular}

\subsection{EXPERIMINTAL}

\subsection{Materials And Equipment}

All starting chemicals used in these measurements were reagent grade. All solutions were prepared using purified, deionized water. Mixtures of solid sodium salts of the organic acids and solutions of sodium nitrate, sodium nitrite, and sodium hydroxide were continuously equilibrated in a water shaker bath (Precision Scientific Model 50) with a constant temperature accuracy of \pm $0.1^{\circ} \mathrm{C}$. The mixtures were contained in $50 \mathrm{~mL}$ polypropylene centrifuge tubes with screw caps so that an airtight seal could be maintained during equilibrium. Mechanical shaking of the mixtures shortened the equilibration times. Initially, the solutions were either saturated with crystalline sodium nitrate or the concentration of sodium nitrate was adjusted to $4.0 \mathrm{M}$ and the initial sodium nitrite concentration was either $2.0 \mathrm{M}$ or $0.97 \mathrm{M}$. Initial sodium hydroxide concentrations varied from $0.0003 \mathrm{M}$ to $2.0 \mathrm{M}$.

\subsection{Analyses}

Measurements of concentrations of sodium salts of nitrate and nitrite were performed using liquid chromatography. A Dionex ${ }^{\star *}$ Model DX-500 liquid chromatograph with a conductivity detector was used for these analyses. Standard solutions for calibration of the chromatograph were prepared from reagent sodium nitrate and sodium nitrite chemicals dried at $110^{\circ} \mathrm{C}$. Standards were run before and after each set of analyses. The observed errors in the analyses of the standards were generally less than $5 \%$ relative error.

Sodium HEDTA and butyrate concentrations were determined by measuring the dissolved TOC using a Dohrmann DC-180 total organic carbon analyzer (Dohrmann, Santa Clara, California). This analyzer was used in the NPOC or non-purgeable organic carbon mode in which

* Versene is a registered trademark of the Dow Chemical Company, Midland, Michigan **Dionex is a registered trademark of Dionex Corporation, Sunnyvale California. 
inorganic carbon was removed from solution by adding acid and the resulting solution was sparged with oxygen gas before analysis of the organic. The HEDTA and butyrate TOC was analyzed by oxidizing it to carbon dioxide and then measuring the amount of carbon dioxide produced. Standard solutions of HEDTA were prepared from recrystallized N-(2hydroxyethyl)ethylendiaminetriacetic acid. Standard solutions of butyric acid were prepared from the reagent grade acid. The instrument was calibrated with these solutions. Each calibration standard and sample was analyzed four times and the relative standard deviations ranged from about $4 \%$ at $4 \mathrm{ppmC}$ to $1 \%$ at $56 \mathrm{ppmC}$.

\subsection{Methods}

Solubilities were determined by measuring concentrations of organics in the aqueous phase of simulated HLW waste mixtures equilibrated at a constant temperature. Solubilities were measured at $25^{\circ} \mathrm{C}, 30^{\circ} \mathrm{C}, 40^{\circ} \mathrm{C}$, and $50^{\circ} \mathrm{C}$. The sodium salt of the organic compound being tested was always present as a crystalline solid during the measurements to ensure saturation of the aqueous solution. For measurements using simulated supernate solutions saturated with sodium nitrate, crystalline sodium nitrate was also always present. The procedure used for conducting the solubility measurements addressed the following four requirements for solubility determination:

1. The temperature of the equilibrating mixtures must be maintained at a constant value.

2. The attainment of equilibrium in the mixtures before sampling the phases must be proven.

3. Sampling the liquid and solid phases must be accomplished without affecting the composition of the phases.

4. The liquid and solid phases must be analyzed to determine their composition and the crystalline identity of the solids.

To determine whether equilibrium had been reached at a given temperature, equilibrium was approached from undersaturation and supersaturation. Also, changes in organic concentrations in the aqueous phases were monitored over time. Solubility equilibrium was achieved if the organic concentrations remained constant over time and the solubilities from undersaturation and supersaturation were the same. Measurements from undersaturation were performed by equilibrating mixtures at the lowest temperature $\left(25^{\circ} \mathrm{C}\right)$, measuring organic concentrations over time, and then repeating the equilibration at increasing temperature steps of $30^{\circ} \mathrm{C}, 40^{\circ} \mathrm{C}$, and 50 ${ }^{\circ} \mathrm{C}$. Equilibration from supersaturated solutions was accomplished by heating the mixtures at 60 ${ }^{\circ} \mathrm{C}$ for two days, cooling and equilibrating at $50^{\circ} \mathrm{C}$, and then repeating the equilibrations at decreasing temperature steps of $40^{\circ} \mathrm{C}, 30^{\circ} \mathrm{C}$, and $25^{\circ} \mathrm{C}$.

Required equilibration times were determined by sampling a given solution periodically until a constant concentration of dissolved organic was observed. Samples of the equilibrated mixtures were removed from the centrifuge tubes and placed in $5-\mathrm{mL}$ syringes fitted with syringe filters $(0.45 \mu \mathrm{m}$, polytetrafluoroethylene). The syringe, filter, and a vial used to receive the filtrate were pre-equilibrated at the sample temperature to prevent crystallization or dissolution during filtration. Approximately $2 \mathrm{mLs}$ of the mixture were filtered through the syringe filter. Exactly 
WHC-EP-0899-1

$1.000 \mathrm{~mL}$ of the filtrate was diluted with $10.00 \mathrm{mLs}$ of deionized water to prevent crystallization. These diluted samples were then analyzed by ion chromatography or by TOC analysis.

To simplify the analyses of the liquid and solid phases, only one organic compound was used in each mixture. This prevented interferences and eliminated the need for separations before analysis.

\subsection{RESULTS AND DISCUSSION}

\subsection{Solution Densities}

The densities of solutions saturated with the organic salts were measured at $25^{\circ} \mathrm{C}, 30^{\circ} \mathrm{C}, 40$ ${ }^{\circ} \mathrm{C}$ and $50^{\circ} \mathrm{C}$ so that concentrations in molalities or weight percent could be calculated from the molar concentrations given in this study. Densities of sodium butyrate and trisodium HEDTA solutions were not measurably different over this temperature range. The solution densities are also an indication of the concentrations of the sodium salts in solution because the salts are more dense than water. Table 3-1 compares densities of the $4.0 \mathrm{M} \mathrm{NaNO}_{3}-0.97 \mathrm{M} \mathrm{NaNO}_{2}$ simulant solution with average densities of saturated solutions of organic salts over the temperature range studied. Densities of the sodium HEDTA saturated solutions are the highest and reflect the high solubility of this salt in the simulated supernate solutions. Densities of solutions saturated with sodium butyrate are not very different from the simulant solution even though the solubilities are quite high. This is probably due to a lower density of the sodium butyrate salt.

Table 3-1. Densities of the simulated supernate solutions and supernate solutions saturated with organic salts at $25^{\circ} \mathrm{C}$ to $50^{\circ} \mathrm{C}$.

\begin{tabular}{|c|c|c|c|}
\hline \multirow{2}{*}{$\begin{array}{l}\text { Initial } \\
{[\mathrm{NaOH}], \mathrm{M}}\end{array}$} & \multicolumn{3}{|c|}{$\begin{array}{l}\text { Densities of Saturated Solutions } \\
\text { at } 25^{\circ} \mathrm{C}, \mathrm{g} / \mathrm{mL}\end{array}$} \\
\hline & Simulant & Butyrate & HEDTA \\
\hline 0.00003 & 1.250 & 1.254 & 1.360 \\
\hline 0.001 & 1.255 & 1.249 & 1.360 \\
\hline 0.01 & 1.244 & 1.252 & 1.359 \\
\hline 0.1 & 1.253 & 1.255 & 1.349 \\
\hline 0.5 & 1.258 & 1.260 & 1.357 \\
\hline 1.0 & 1.286 & 1.278 & 1.344 \\
\hline 2.0 & 1.320 & 1.305 & 1.366 \\
\hline
\end{tabular}

Solution densities were also measured for supernates saturated with both the organic salts and crystalline sodium nitrate at $25^{\circ} \mathrm{C}, 30^{\circ} \mathrm{C}, 40^{\circ} \mathrm{C}$ and $50^{\circ} \mathrm{C}$ over a range of initial sodium hydroxide concentrations ( $0.1 \mathrm{M}$ to $2.0 \mathrm{M}$ ). These data are plotted in Figures 3-1 to 3-4 for each of the organic salts studied. Some of these densities approach $1.5 \mathrm{~g} / \mathrm{mL}$ due to the dissolution of additional sodium nitrate compared to the simulated supernates not saturated with this salt. Higher densities of these solutions at the higher temperatures reflect the increasing solubility of crystalline sodium nitrate. Detailed density data are given in Appendix B. 

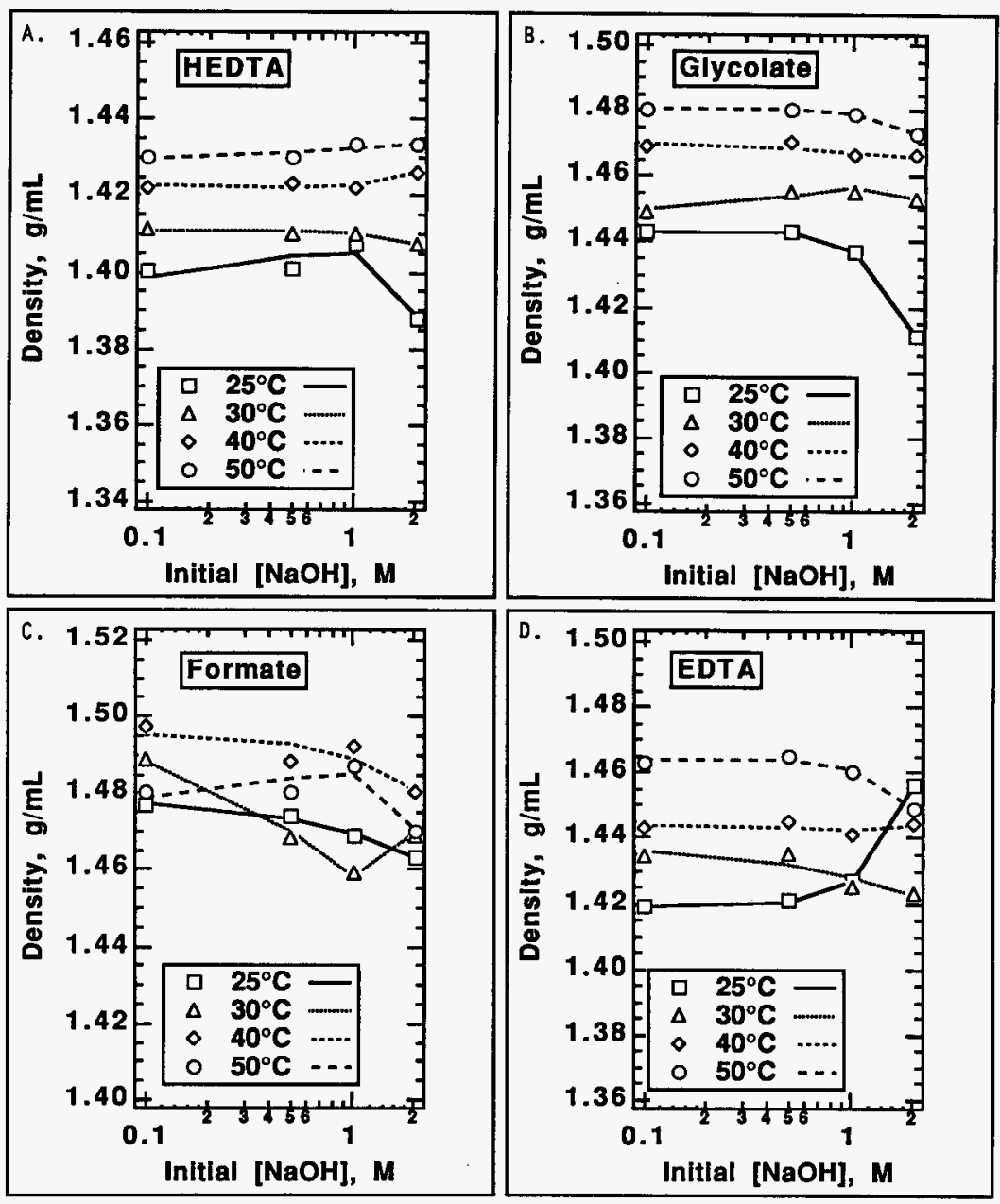

Figure 3-1. Densities of simulated supernate solutions saturated with crystalline $\mathrm{NaNO}_{3}$ and crystalline sodium HEDTA (A), glycolate (B), formate (C), and EDTA (D) at $25^{\circ} \mathrm{C}, 30^{\circ} \mathrm{C}, 40^{\circ} \mathrm{C}$, and $50^{\circ} \mathrm{C}$ for various initial sodium hydroxide concentrations. 

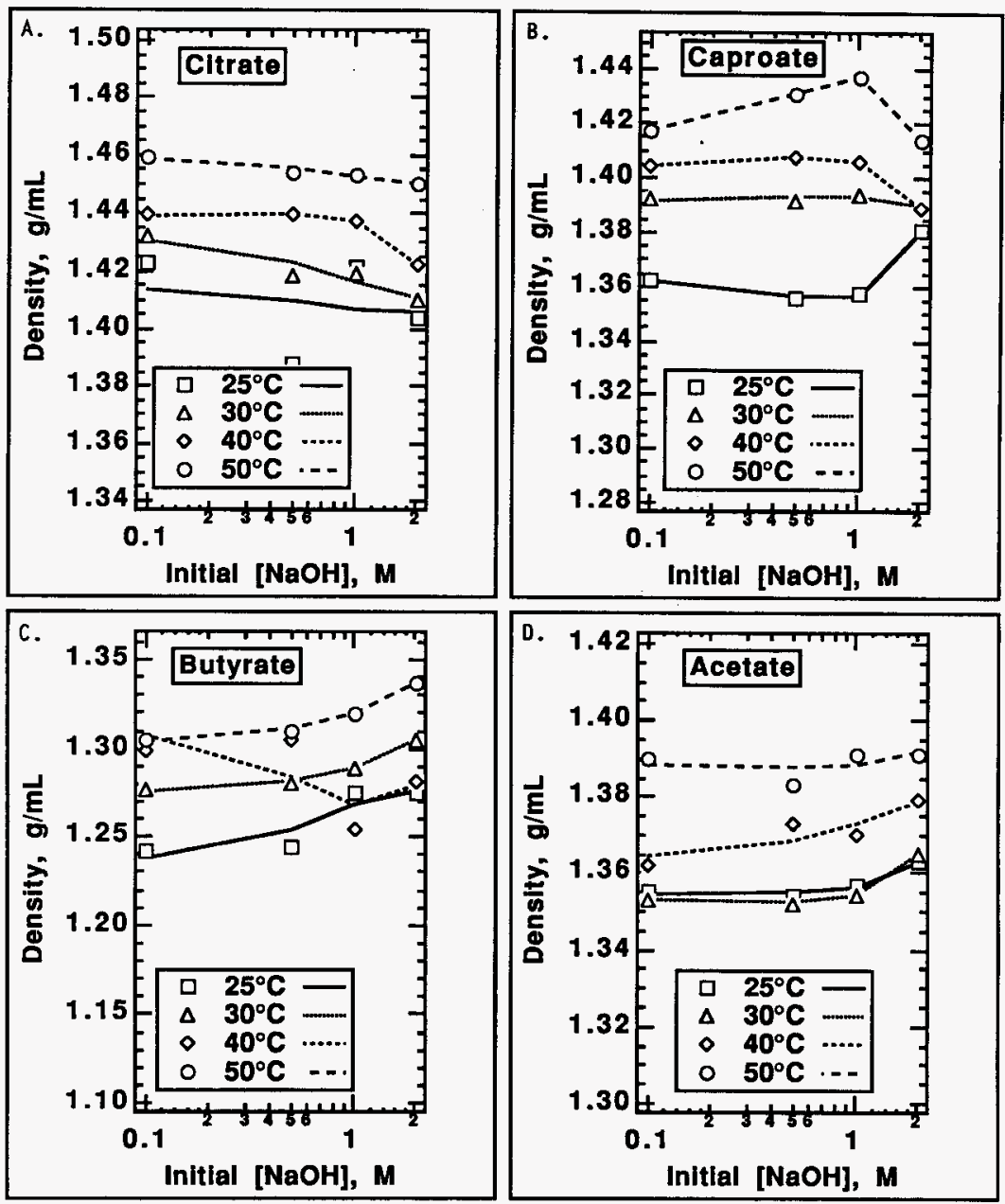

Figure 3-2. Densities of simulated supernate solutions saturated with crystalline $\mathrm{NaNO}_{3}$ and crystalline sodium citrate (A), caproate (B), butyrate (C), and acetate (D) at $25^{\circ} \mathrm{C}, 30^{\circ} \mathrm{C}, 40^{\circ} \mathrm{C}$, and $50^{\circ} \mathrm{C}$ for various initial sodium hydroxide concentrations. 

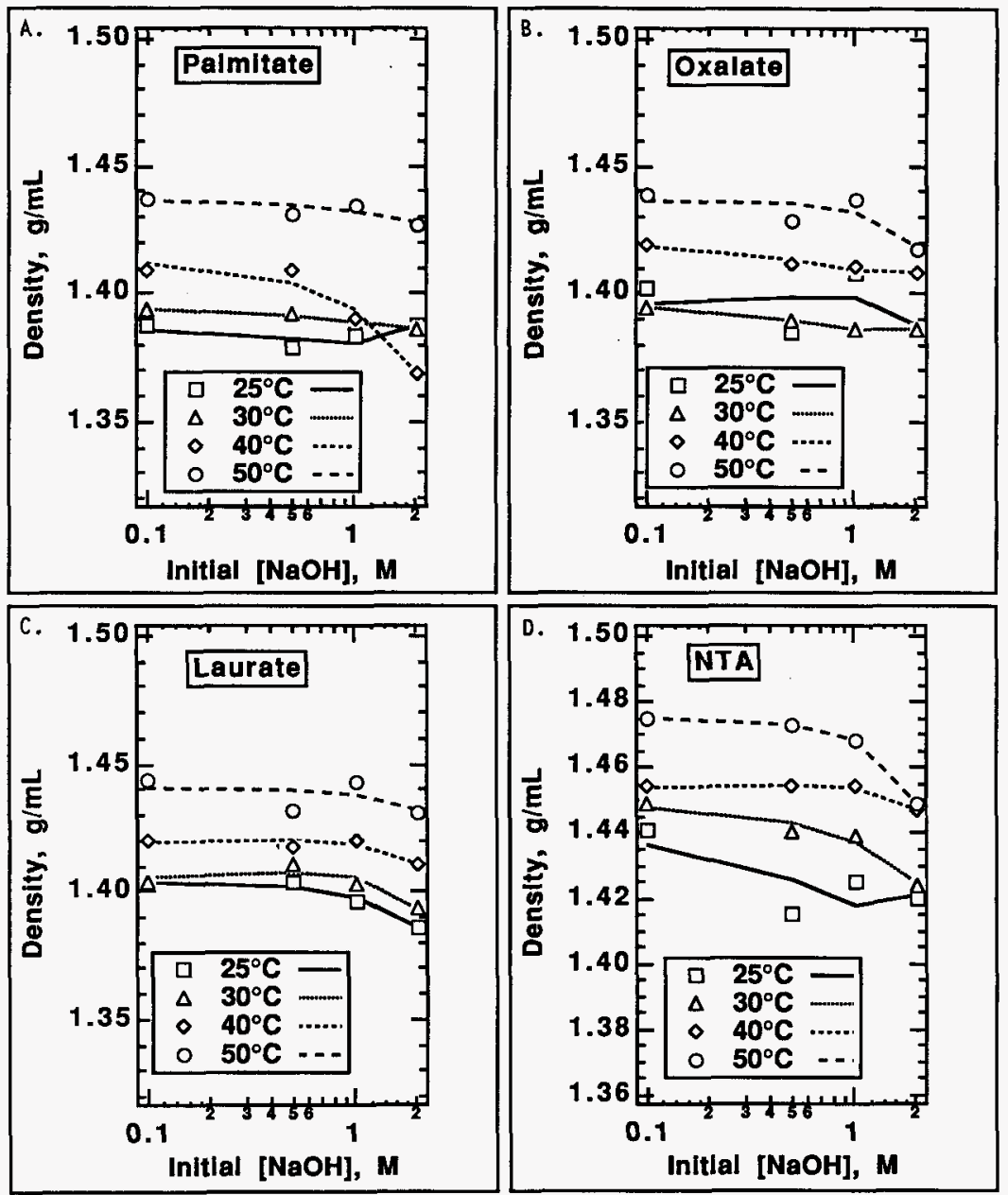

Figure 3-3. Densities of simulated supernate solutions saturated with crystalline $\mathrm{NaNO}_{3}$ and crystalline sodium palmitate (A), oxalate (B), laurate (C), and NTA (D) at $25^{\circ} \mathrm{C}, 30^{\circ} \mathrm{C}, 40^{\circ} \mathrm{C}$, and $50^{\circ} \mathrm{C}$ for various initial sodium hydroxide concentrations. 


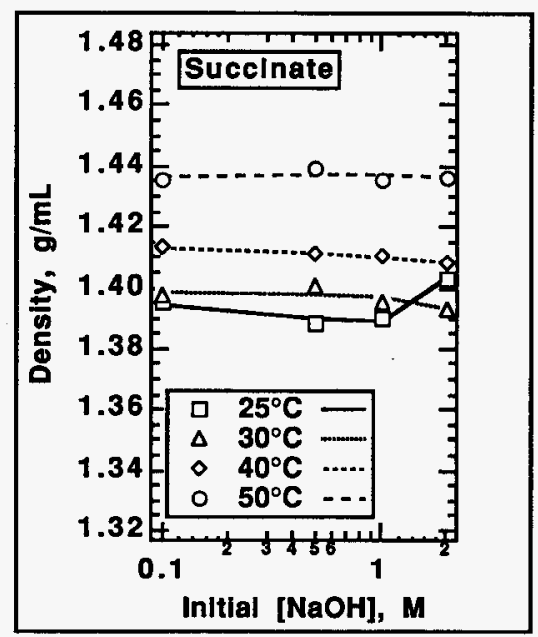

Figure 3-4. Densities of simulated supernate solutions saturated with crystalline $\mathrm{NaNO}_{3}$ and crystalline sodium succinate at $25^{\circ} \mathrm{C}, 30^{\circ} \mathrm{C}, 40^{\circ} \mathrm{C}$, and $50^{\circ} \mathrm{C}$ for various initial sodium hydroxide concentrations.

\subsection{Evidence For Equilibrium}

Evidence for attainment of dissolution/crystallization equilibrium was obtained at each of the four temperatures studied. As described in the Methods section, solubilities were measured from undersaturation and supersaturation. The temperature was held constant over a period of time to allow equilibration. Because the time required for equilibration was unknown, samples of the aqueous phases were taken periodically to monitor changes in organic concentrations. Average concentrations of butyrate and HEDTA over all the seven initial sodium hydroxide concentrations at $25^{\circ} \mathrm{C}, 30^{\circ} \mathrm{C}, 40$ ${ }^{\circ} \mathrm{C}$, and $50^{\circ} \mathrm{C}$ are shown in Table 3-2 so that an overall trend of dissolution or crystallization could be observed. .

The data from undersaturation measurements clearly show that butyrate and HEDTA concentrations were constant over the 21-day period and that equilibrium was reached during this time. From supersaturation, equilibrium was also attained rapidly for these compounds. The equilibrium solubility values reported here for butyrate and HEDTA are averages of those obtained from supersaturation and undersaturation. 
Table 3-2. Average concentrations of organics versus time over all sodium hydroxide concentrations.

\begin{tabular}{lllll|llll}
\hline $\begin{array}{l}\text { Equilibration } \\
\text { Time, Days }\end{array}$ & \multicolumn{9}{c|}{ Average [Butyrate], $\mathrm{M}$} & \multicolumn{5}{c}{ Average [HEDTA], M } \\
\hline $\begin{array}{l}\text { From } \\
\text { Undersaturation }\end{array}$ & $25^{\circ} \mathrm{C}$ & $30^{\circ} \mathrm{C}$ & $40^{\circ} \mathrm{C}$ & $50^{\circ} \mathrm{C}$ & $25^{\circ} \mathrm{C}$ & $30^{\circ} \mathrm{C}$ & $40^{\circ} \mathrm{C}$ & $50^{\circ} \mathrm{C}$ \\
\hline 7 & 3.56 & 3.66 & 3.59 & 3.55 & 1.63 & 1.73 & 1.74 & 1.73 \\
14 & 3.62 & 3.67 & 3.63 & 3.50 & 1.77 & 1.76 & 1.74 & 1.74 \\
21 & 3.65 & 3.63 & 3.51 & 3.50 & 1.78 & 1.78 & 1.74 & 1.73 \\
\hline From & & & & & & & & \\
Supersaturation & & & & & & & & \\
7 & $\mathrm{ND}$ & $\mathrm{ND}$ & $\mathrm{ND}$ & $\mathrm{ND}$ & 1.62 & 1.58 & 1.68 & 1.69 \\
14 & $\mathrm{ND}$ & $\mathrm{ND}$ & $\mathrm{ND}$ & $\mathrm{ND}$ & 1.76 & 1.64 & 1.70 & 1.62 \\
21 & $\mathrm{ND}$ & $\mathrm{ND}$ & $\mathrm{ND}$ & $\mathrm{ND}$ & 1.73 & 1.57 & 1.69 & 1.73 \\
\hline
\end{tabular}

${ }^{*} \mathrm{ND}=$ not determined.

\subsection{Solution Volume Increases}

Because of their high solubilities, dissolution of sodium butyrate and HEDTA in the simulant solutions resulted in significant volume increases in these solutions. This volume increase caused a corresponding dilution of the initial concentrations of sodium nitrate, nitrite, and hydroxide. The volume increases shown in Table 3-3 (for sodium hydroxide concentrations less than $0.1 \mathrm{M}$ ) were calculated from the change in concentration of nitrate after dissolution of the organics, according to the equation,

$\%$ Volume Increase $=100(1-$ Final Nitrate Concentration/Initial Nitrate Concentration $)$.

Table 3-3. Volume increases due to dissolution of organic salts.

\begin{tabular}{lcccc} 
& \multicolumn{5}{c}{$\%$ Volume Increase } \\
\cline { 2 - 5 } Organic Salt & $50^{\circ} \mathrm{C}$ & $40^{\circ} \mathrm{C}$ & $30^{\circ} \mathrm{C}$ & $25^{\circ} \mathrm{C}$ \\
\hline Butyrate & 52 & 51 & 44 & 42 \\
HEDTA & 14 & 16 & 16 & 18 \\
\hline
\end{tabular}

\subsection{Sodium Butyrate Solubility}

Sodium butyrate is very soluble in simulated HLW supernate solutions. At low sodium hydroxide concentrations, butyrate solubilities as high as $4.0 \mathrm{M}$ were observed. The temperature effect on solubility was relatively small compared to the other compounds studied thus far. No clear trend in the effect of temperature on butyrate solubility was observed. Figure 3-5A shows that the solubility decreased as sodium hydroxide concentration increased, probably because of the common ion effect of $\mathrm{Na}^{+}$. Literature data (Bury and Owens 1935) show a strong effect of sodium hydroxide on sodium butyrate solubility. At about $5 \mathrm{M} \mathrm{NaOH}$ (total sodium in the current test solutions, excluding that sodium from sodium butyrate, is about $5 \mathrm{M}$ ) these data 

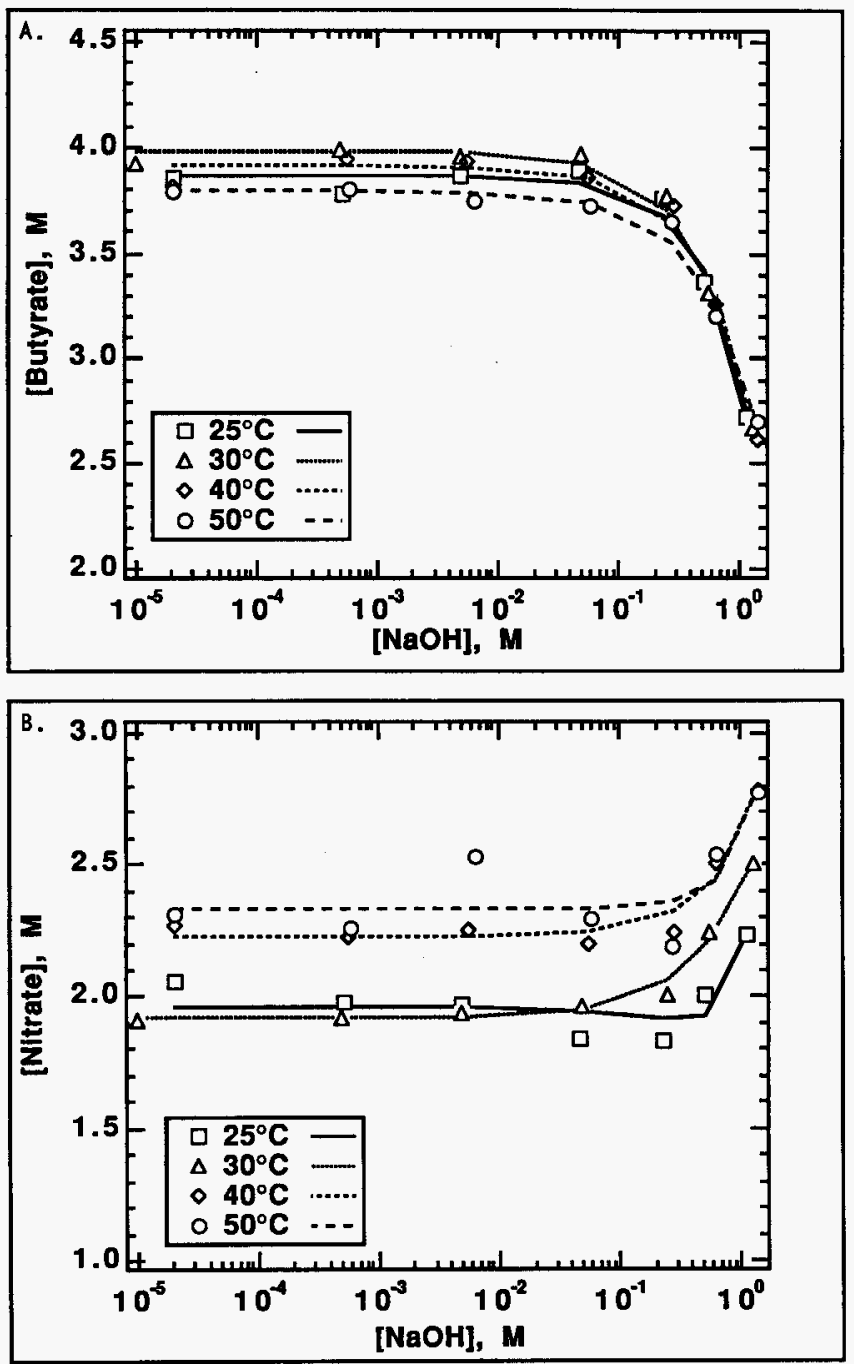

Figure 3-5. Solubility of sodium butyrate in $\mathrm{NaNO}_{3}-\mathrm{NaNO}_{2}$ solutions at $25^{\circ} \mathrm{C}, 30^{\circ} \mathrm{C}, 40^{\circ} \mathrm{C}$, and $50^{\circ} \mathrm{C}$ for various sodium hydroxide concentrations (A), and measured sodium nitrate concentrations in the same solutions (B). 


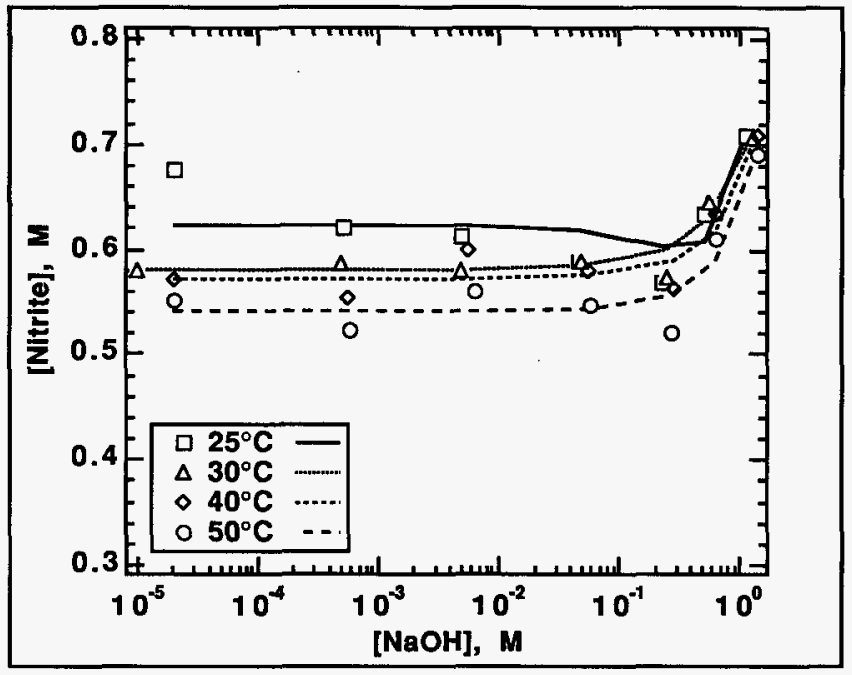

Figure 3-6. Measured sodium nitrite concentrations in solutions where the solubility of sodium butyrate was determined in $\mathrm{NaNO}_{3}-\mathrm{NaNO}_{2}$ solutions at $25^{\circ} \mathrm{C}, 30^{\circ} \mathrm{C}, 40^{\circ} \mathrm{C}$, and $50^{\circ} \mathrm{C}$ and sodium hydroxide concentrations varied.

predict a solubility of about $5 \mathrm{M}$ sodium butyrate. This is in rough agreement with the data presented in this document.

The effect of diluting the original simulant solution by sodium butyrate dissolution can be seen in Figures 3-5B and 3-6. The original nitrate and nitrite concentrations (4.0 $\mathrm{M}$ and $0.97 \mathrm{M}$, respectively) have been diluted by 42 to $52 \%$. At higher hydroxide concentrations, nitrate and nitrite concentrations increase due to the decreasing solubility of the butyrate. Detailed solubility measurement data for the organic salts reported in this document are given in Appendix A. Sodium butyrate apparently forms a crystalline hydrate, $\mathrm{CH}_{3} \mathrm{CH}_{2} \mathrm{CH}_{2} \mathrm{COONa} \cdot \mathrm{H}_{2} \mathrm{O}$, and an acid adduct, $\mathrm{CH}_{3} \mathrm{CH}_{2} \mathrm{CH}_{2} \mathrm{COONa} \cdot \mathrm{CH}_{3} \mathrm{CH}_{2} \mathrm{CH}_{2} \mathrm{COOH}$ in equilibrium with the simulated waste solutions.

Sodium butyrate solubilities in supernate simulants that are saturated with crystalline sodium nitrate are lower than those given above, as expected due to higher concentrations of the common ion, sodium. Figure 3-7 shows solubilities ranging from about 2.2 to $3.4 \mathrm{M}$ sodium butyrate, which is about a half molar less than for solutions not fully saturated with sodium nitrate. The butyrate solubility actually decreases with increasing temperature because more sodium nitrate dissolves in the solutions at higher temperatures. 
WHC-EP-0899-1
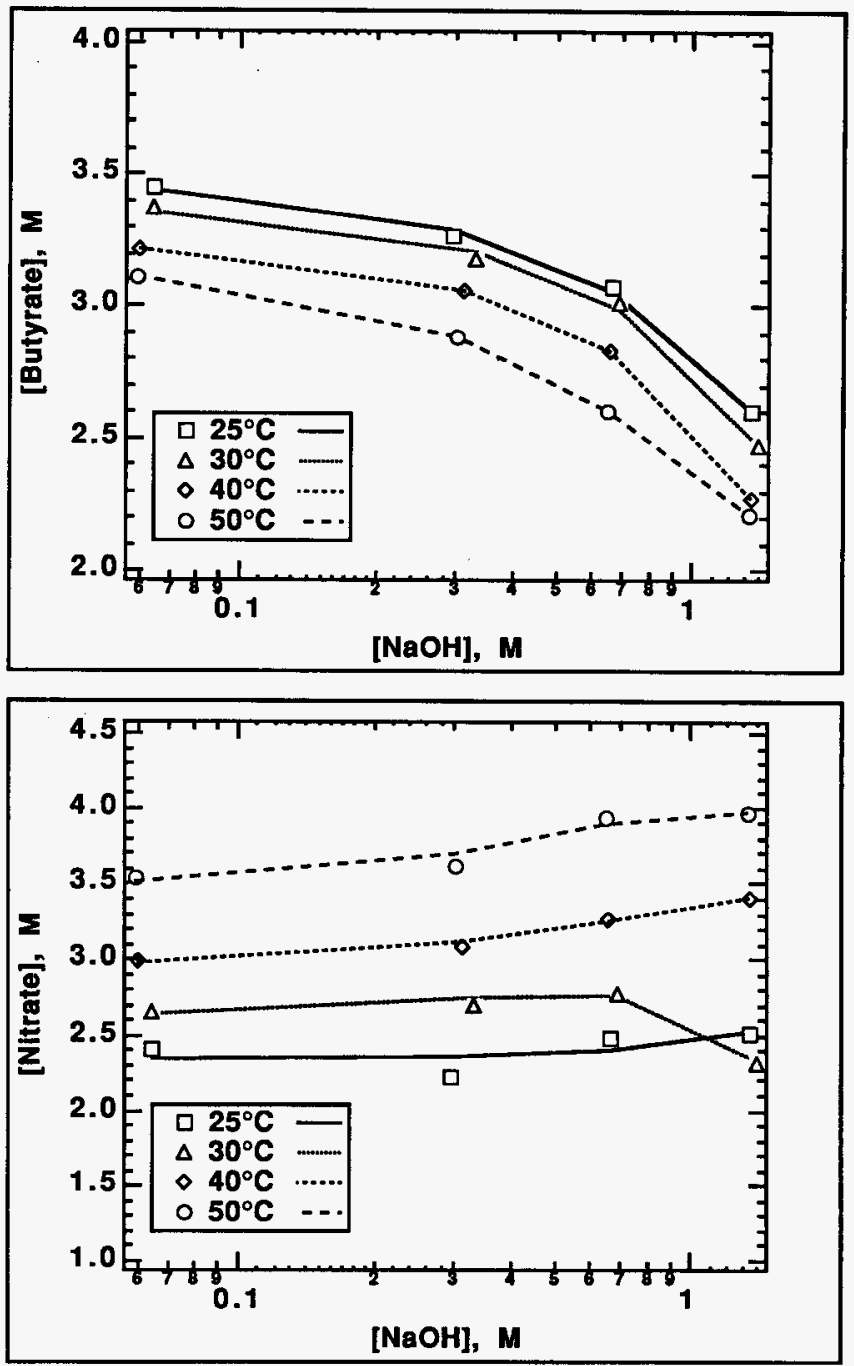

Figure 3-7. Solubility of sodium butyrate in $\mathrm{NaNO}_{3}-\mathrm{NaNO}_{2}$ solutions saturated with crystalline $\mathrm{NaNO}_{3}$ at 25 ${ }^{\circ} \mathrm{C}, 30^{\circ} \mathrm{C}, 40^{\circ} \mathrm{C}$, and $50^{\circ} \mathrm{C}$ for various sodium hydroxide concentrations (A), and measured sodium nitrate concentrations in the same solutions (B). 


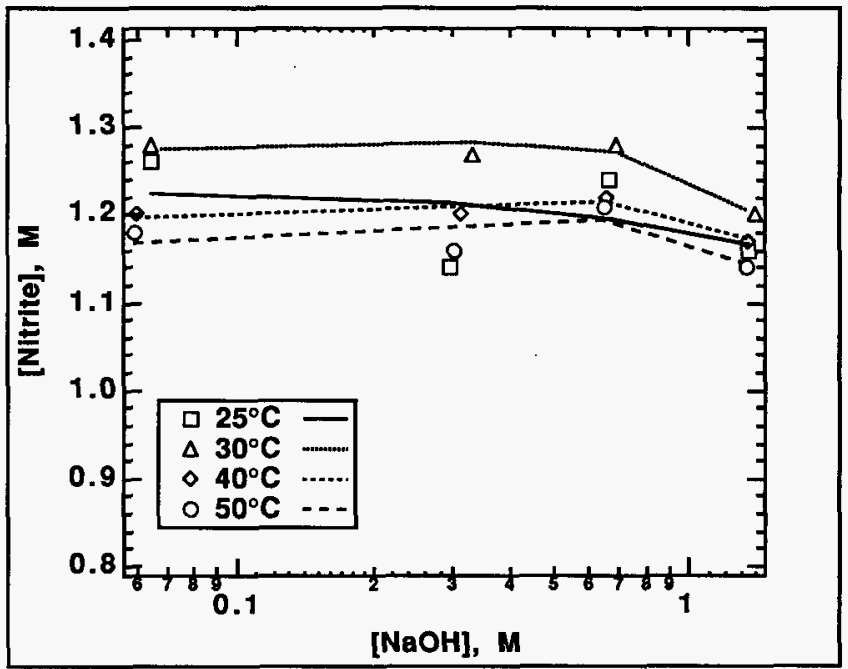

Figure 3-8. Measured sodium nitrite concentrations in solutions where the solubility of sodium butyrate was determined. These solutions were saturated with crystalline $\mathrm{NaNO}_{3}$ at $25^{\circ} \mathrm{C}, 30^{\circ} \mathrm{C}, 40^{\circ} \mathrm{C}$, and $50^{\circ} \mathrm{C}$, the initial sodium nitrite concentration was $2.0 \mathrm{M}$, and initial sodium hydroxide concentrations varied from $0.1 \mathrm{M}$ to $2.0 \mathrm{M}$.

\subsection{Trisodium HEDTA Solubility}

Sodium HEDTA was also quite soluble in the simulated HLW supernate solutions. At low sodium hydroxide concentrations, HEDTA solubilities as high as $1.8 \mathrm{M}$ were observed.

Solubilities did not measurably change as the temperature was raised, and the small temperature effect on solubility was observed over all the sodium hydroxide concentrations studied. Solubilities were lowered significantly by increasing the sodium hydroxide concentration, as shown in Figure 3-9A. This is due to the common ion effect of $\mathrm{Na}^{+}$and the effects of high ionic strength in the simulant solutions. The $41 \%$ (by mass) solubility at $25^{\circ} \mathrm{C}$ reported by The Dow Chemical Versene literature (about $1.6 \mathrm{M}$ ) in pure water is reasonably near the solubilities measured here in supernate solutions (about 1.5 to $1.8 \mathrm{M}$ ). The effect of diluting the simulant by sodium EDTA dissolution on nitrate and nitrite concentrations can be seen in Figures 3-9B and 310. The original nitrate and nitrite concentrations ( $4.0 \mathrm{M}$ and $0.97 \mathrm{M}$, respectively) have been diluted by $14 \%$ to $18 \%$. At higher hydroxide concentrations, nitrate and nitrite concentrations increase due to the decreasing solubility of the EDTA. The likely crystalline phase for the trisodium HEDTA in the present equilibrium solubility mixtures is the dihydrate, $\left(\mathrm{HOCH}_{2} \mathrm{CH}_{2}\right)\left(\mathrm{NaOOCCH}_{2}\right) \mathrm{NCH}_{2} \mathrm{CH}_{2} \mathrm{~N}\left(\mathrm{CH}_{2} \mathrm{COONa}\right)_{2} \cdot 2 \mathrm{H}_{2} \mathrm{O}$. 

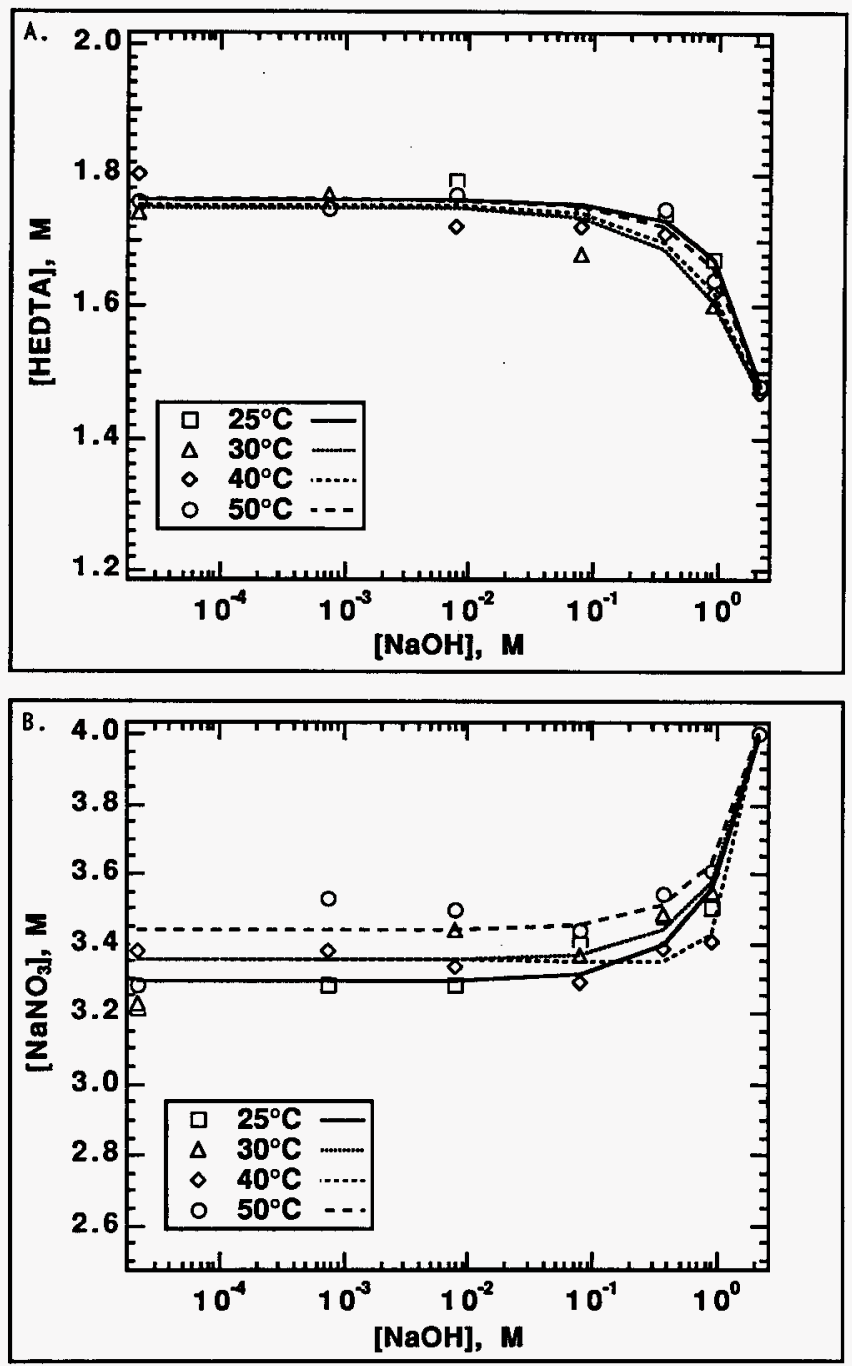

Figure 3-9. Solubility of sodium HEDTA in $\mathrm{NaNO}_{3}-\mathrm{NaNO}_{2}$ solutions at $25^{\circ} \mathrm{C}, 30^{\circ} \mathrm{C}, 40^{\circ} \mathrm{C}$, and $50^{\circ} \mathrm{C}$ for various sodium hydroxide concentrations (A), and measured sodium nitrate concentrations in the same solutions (B). 


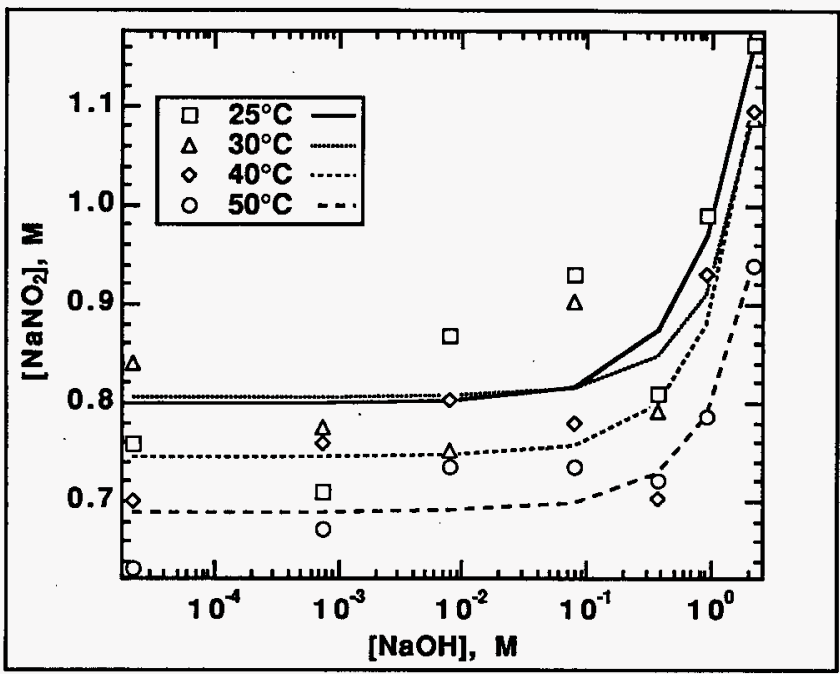

Figure 3-10. Measured sodium nitrite concentrations in solutions used above for sodium HEDTA solubility measurements at $25^{\circ} \mathrm{C}, 30^{\circ} \mathrm{C}, 40^{\circ} \mathrm{C}$, and $50^{\circ} \mathrm{C}$ and for various sodium hydroxide concentrations.

Sodium HEDTA solubilities in supernate simulants that were saturated with crystalline sodium nitrate were lower than those given above, as expected due to higher concentrations of the common ion, sodium . Figure 3-11A shows solubilities ranging from about 1.09 to $1.19 \mathrm{M}$ sodium HEDTA, which is about a half molar less than for solutions not fully saturated with sodium nitrate. The HEDTA solubilities are not measurably different over the temperature range studied $\left(25^{\circ} \mathrm{C}\right.$ to $\left.50^{\circ} \mathrm{C}\right)$ with increasing temperature even though more sodium nitrate dissolves in the solutions at higher temperatures (Figure 3-11B). 

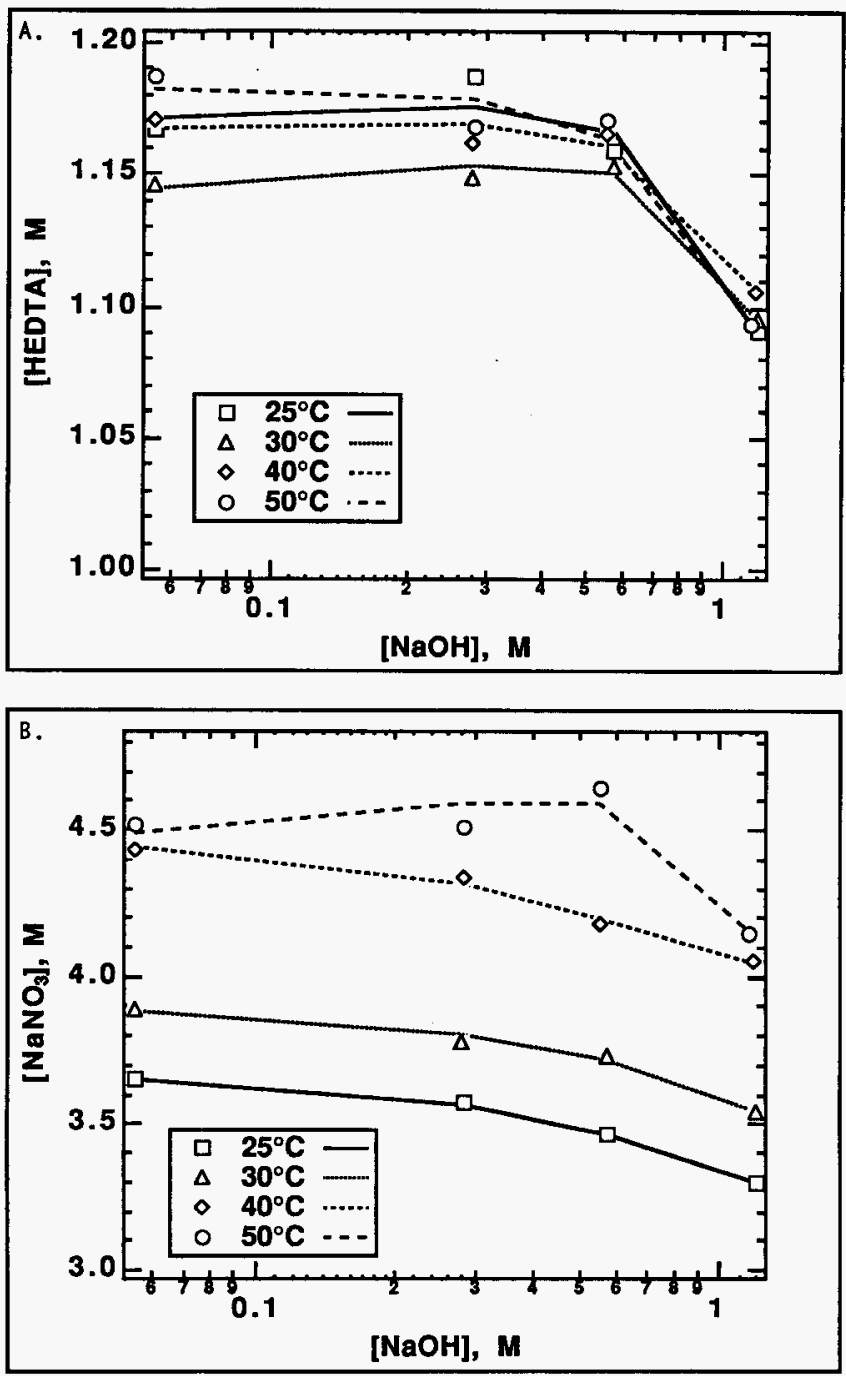

Figure 3-11. Solubility of sodium HEDTA in $\mathrm{NaNO}_{3}-\mathrm{NaNO}_{2}$ solutions saturated with crystalline $\mathrm{NaNO}_{3}$ at 25 ${ }^{\circ} \mathrm{C}, 30^{\circ} \mathrm{C}, 40^{\circ} \mathrm{C}$, and $50^{\circ} \mathrm{C}$ for various sodium hydroxide concentrations (A), and measured sodium nitrate concentrations in the same solutions (B). 


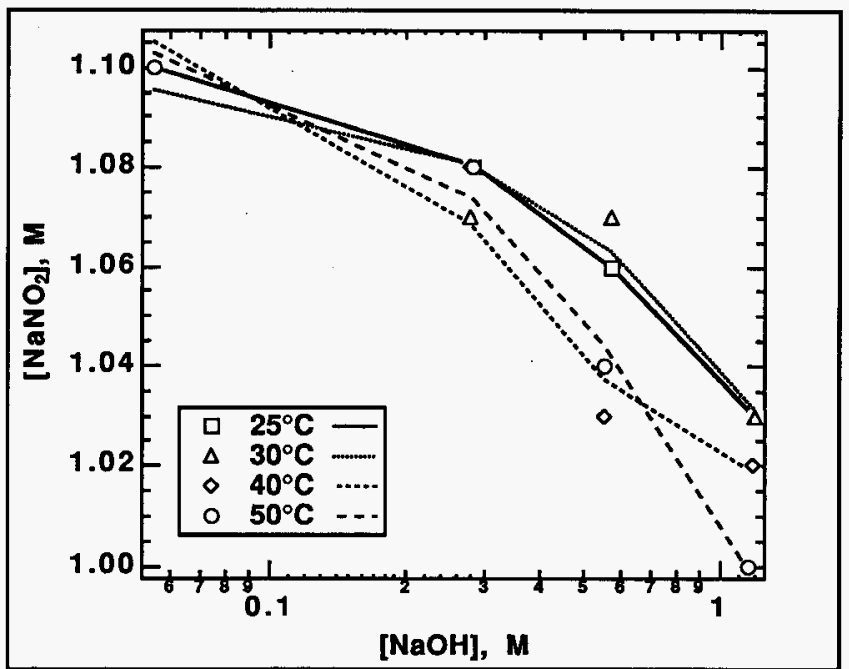

Figure 3-12. Measured sodium nitrite concentrations in solutions where the solubility of sodium HEDTA was determined. These solutions were saturated with crystalline $\mathrm{NaNO}_{3}$ at $25^{\circ} \mathrm{C}, 30^{\circ} \mathrm{C}, 40^{\circ} \mathrm{C}$, and $50^{\circ} \mathrm{C}$, the initial sodium nitrite concentration was $2.0 \mathrm{M}$, and initial sodium hydroxide concentrations varied from $0.1 \mathrm{M}$ to $2.0 \mathrm{M}$.

\subsection{HLW Tank Total Organic Carbon Values}

The solubility data presented above can be used to determine if solid sodium salts of organic compounds can exist in the HLW tanks at the Hanford Site. If concentrations of these salts measured in the supernate solutions are near the solubility limits measured in this study, then solid organic salts can be presumed to be present in the waste (assuming, of course, that the supernate is in equilibrium with the salts). Ideally, concentrations of the individual salts in actual supernate solutions should be obtained. Unfortunately, only TOC concentrations have been measured in supernate solutions for most of the waste tanks. The TOC values in grams of organic carbon per liter of solution have been collected for supernate solutions in $61 \mathrm{HLW}$ tanks at the Hanford Site. These include values from single-shell tanks (Van Vleet 1993a) and doubleshell tanks (Van Vleet 1993b). The frequency distribution for these 61 values is shown in Figure 3-13. The bulk of the TOC values are less than $14 \mathrm{~g} / \mathrm{L}$ of organic carbon. For single-shell tanks, Toth et al. (1995) have calculated a mean value of $5.2 \pm 1.1 \mathrm{~g} / \mathrm{L}$ organic carbon (at the $95 \%$ confidence level) for the tank supernate solutions. This mean was calculated from analyses of 143 samples from 78 different single-shell tanks.

If the tank TOC values are compared with solubilities for the nine organic salts studied, only 


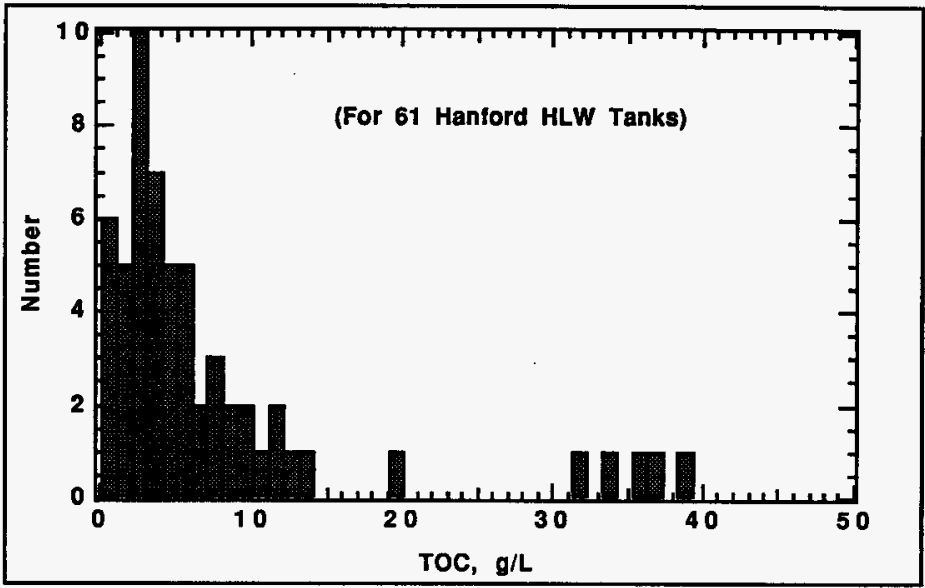

Figure 3-13. Frequency distribution of total organic carbon (TOC) concentrations measured in supernate solutions in 61 different Hanford Site HLW tanks.

oxalate has a low enough solubility to be present as a solid in the tanks. This can be seen by comparing the TOC values in Table 3-4, which gives the ranges of measured solubilities of the

Table 3-4. Comparison of measured organic sodium salt solubility ranges in units of molarity and total organic carbon concentrations (TOC).

Solutions not saturated with $\mathrm{NaNO}_{3}$

Solutions saturated with $\mathrm{NaNO}_{3}$

\begin{tabular}{lcccc}
\hline Organic salt & Solubility Range*, & TOC Range, $\mathrm{gC} / \mathrm{L}$ & Solubility Range, $\mathrm{M}$ & TOC Range, $\mathrm{gC/L}$ \\
\hline Glycolate & $4.4-5.8$ & $106-140$ & $\mathrm{ND}$ & $\mathrm{ND}$ \\
Succinate & $0.9-2.3$ & $43-110$ & $\mathrm{ND}$ & $\mathrm{ND}$ \\
Caproate & $0.2-1.7$ & $14-122$ & $\mathrm{ND}$ & $\mathrm{ND}$ \\
Dibutyphosphate & $>0.9$ & $>86$ & $\mathrm{ND}$ & $\mathrm{ND}$ \\
Oxalate & $0.004-.015$ & $0.1-0.36$ & $\mathrm{ND}$ & $\mathrm{ND}$ \\
Citrate & $0.6-1.2$ & $43-86$ & $\mathrm{ND}$ & $\mathrm{ND}$ \\
Formate & $6.8-9.8$ & $82-118$ & $\mathrm{ND}$ & $\mathrm{ND}$ \\
EDTA & $0.7-1.4$ & $84-168$ & $\mathrm{ND}$ & $\mathrm{ND}$ \\
NTA & $1.3-1.7$ & $94-122$ & $\mathrm{ND}$ & $\mathrm{ND}$ \\
Butyrate & $2.6-4.0$ & $125-192$ & $2.2-3.5$ & $106-168$ \\
HEDTA & $1.5-1.8$ & $180-216$ & $1.09-1.19$ & $131-143$ \\
\hline
\end{tabular}

*Over all sodium hydroxide concentrations and temperatures.

**ND = not determined.

individual organic salts in terms of TOC, with the tank values. Even if all the dissolved organic carbon in the tank supernates is pure butyrate, glycolate, succinate, caproate, dibutyl phosphate, 
WHC-EP-0899-1

citrate, formate , EDTA, HEDTA, or NTA, there is not enough in solution to reach saturation and precipitate these organics.

\subsection{CONCLUSIONS}

The solubilities of sodium butyrate and HEDTA in HLW tank supernate solutions measured in the present work are high over the temperature and sodium hydroxide concentration ranges expected in the tanks. The solubilities of these compounds are similar (in terms of TOC) to sodium citrate, formate, EDTA, NTA, glycolate, succinate, caproate, and dibutyl phosphate, which were previously reported (Barney 1994 and 1995). The high solubilities will prevent solid sodium salts of these ten organic acids from precipitating from tank supernate solutions. The TOC analyses of actual tank supernates are generally much lower than the TOC ranges for the simulated supernate solutions saturated (at the solubility limit) with the organic salts. This is true even if all the dissolved carbon in a given tank supernate is due to only one of the ten compounds (a very unlikely situation). Sodium caproate solubility at low temperatures and high hydroxide concentrations is below the TOC for several tanks, but is not expected to be present in high concentrations since it is only one of many possible degradation products of the normal paraffin hydrocarbon (NPH) solvent used in the PUREX process at Hanford (Babad et al. 1993). This compound has not yet been identified in actual waste. Because these ten organic compounds are not likely to exist as solids in the saltcake or sludge layers of the tanks, but only as aqueous solutions, self-propagating reactions with nitrates or nitrites are unlikely.

The low solubility of sodium oxalate (far below most measured tank supernate TOC values) will allow it to precipitate in some tanks with nitrate and nitrite salts. The energy content of oxalate is quite low and mixtures with sodium nitrate/nitrite will not propagate Webb et al. 1994).

\subsection{FUTURE WORK}

Solubilities of additional organic compounds known to exist in the HLW tanks will be measured. These include three compounds that have been found in actual tank waste recently by Campbell et al., 1994 and 1995. They are sodium acetate and sodium iminodiacetate, $\mathrm{NH}\left(\mathrm{CH}_{2} \mathrm{COONa}\right)_{2}$. In addition to these compounds, solubility measurements are underway on the long-chain carboxylic acid salts, sodium laurate, $\mathrm{CH}_{3}\left(\mathrm{CH}_{2}\right)_{10} \mathrm{COONa}$, and sodium palmitate, $\mathrm{CH}_{3}\left(\mathrm{CH}_{2}\right)_{14} \mathrm{COONa}$. These compounds are possible degradation products of NPH.

Additional work remains to be done on determining whether or not organic complexes or compounds with metal ions can form and precipitate under waste conditions. Based on the observations described in the 1995 Progress Report (Barney, 1995) on aluminum oxalate, iron DBP, and aluminum DBP, organic complexes/compounds are not stable as long as significant concentrations of free hydroxide are present. Metal-organic complexes that have high stability, such as EDTA complexes with thorium, bismuth, or zirconium, will be examined to determine their stabilities and solubilities under tank supernate conditions. 


\section{WHC-EP-0899-1}

The effects of dissolved organics in supernate solutions on the solubility of other organic compounds needs to be determined. It seems likely that the presence of organic sodium salts in solution will lower the solubility of other organic sodium salts because of the common ion effect of sodium. There will be other factors involved, however, that could influence organic salt solubility such as organic anion-anion interactions. Several pairs of organic salts will be studied including acetate-citrate and EDTA-NTA.

\subsection{REFERENCES}

Babad, H., D. M. Camaioni, M. A. Lilga, and D. M. Strachan, 1993, "Tank Waste Chemistry - A New Understanding of Waste Aging," WHC-SA-1694-FP, Westinghouse Hanford Company, Richland, Washington.

Ashby, E. C. ,A. Annis, E. K. Barefield, D. Boatright, F. Doctorovich, C. L. Liotta, H. M. Neumann, A. Konda, C.-F. Yao, K. Zang, and N. G. Duffie, 1994, "Synthetic Waste Mechanism Studies," WHC-EP-0823, Westinghouse Hanford Company, Richland, Washington.

Banney, G. S., 1994, "The Solubilities of Significant Organic Compounds in HLW Tank Supernate Solutions FY1995 Progress Report", WHC-EP-0899, Westinghouse Hanford Company, Richland, Washington.

Barney, G. S., 1995, "The Solubilities of Significant Organic Compounds in HLW Tank Supernate Solutions," WHC-SA-2565-FP, Westinghouse Hanford Company, Richland, Washington.

Bury and Owens, 1935, Trans. Faraday Soc., 31, 480-2.

Camaioni, D. M., W. D. Samuals, B. D. Lenihan, S. A. Clauss, K.L. Wahl, J. A. Campbell, and W. J. Shaw, 1995, "Organic Tanks Safety Program FY95 Waste Aging Studies", PNL-10161, Pacific Northwest National Laboratory, Richland, Washington.

Campbell, J. A., S. Clauss, K. Grant, V. Hoopes, B. Lerner, R. Lucke, G. Mong, J. Rau, and R. Steele, 1994, "Flammable Gas Safety Program - Analytical Methods Development: FY 1993 Progress Report," PNL9062, Pacific Northwest Laboratory, Richland, Washington.

Campbell, J. A., S. Clauss, K. Grant, V. Hoopes, G. Mong, J. Rau, R. Scheele, K. L. Wahl, 1995, "Organic Analysis and Analytical Development: FY 1995 Progress Report," PNL-10776, Pacific Northwest Laboratory, Richland, Washington.

Delegard, C. H., 1987, "Identities of HEDTA and Glycolate Degradation Products in Simulated Hanford HighLevel Waste," RHO-RE-ST-55 P, Rockwell Hanford Operations, Richland, Washington.

Toste, A. P., T. J. Lechner-Fish, D. J. Hendren, R, D, Scheele, And W. G. Richmond, 1988, "Analysis of Organics in Highly Radioactive Wastes", J. Radioanal. and Nucl. Chem., Art., 123:149-166.

Toth, J. J., J. G. Hill, P. G. Heasler, P. D. Whitney, and M. E. Lerchen, 1995, "Analysis of Organic Carbon and Moisture in Hanford Single-Shell Tank Waste", PNL-10360, Pacific Northwest Laboratory, Richland, Washington.

Van Vleet, R. J., 1993a, "Radionuclide and Chemical Irventories for the Single Shell Tanks," WHC-SD-WM-TI565, Westinghouse Hanford Company, Richland, Washington.

Van Vleet, R. J., 1993b, "Radionuclide and Chemical Inventories for the Double Shell Tanks," WHC-SD-WM-TI543, Westinghouse Hanford Company, Richland, Washington.

Webb, A. L., J. L. Stewart, M. G. Plys, B. Malinovuic, J. M. Grigsby, D. M. Camaioni, P. Heasler, and J. J. Toth, 1995, "Preliminary Safety Criteria for Organic Watchlist Tanks at the Hanford Site", WHC-SDSARR-033 Rev. 0, Westinghouse Hanford Company, Richland, Washington. 
$7 \%$ RENTIONALLY

I. DLANTENALLY 
WHC-EP-0899-1

APPENDIX A

SOLUBILITIES OF ORGANIC SALTS AND SOLUTION COMPOSITIONS 
WHC-EP-0899-1

HEDTA Solubilities

(Molar Concentrations)

\begin{tabular}{|c|c|c|c|c|}
\hline \multirow{2}{*}{$\begin{array}{l}\text { Initial } \\
{[\mathrm{NaOH}]}\end{array}$} & \multicolumn{4}{|c|}{ EQUILIBRIUM SOLUBILITIES } \\
\hline & [HEDTA],50 ${ }^{\circ} \mathrm{C}$ & [HEDTA],, $0^{\circ} \mathrm{C}$ & [HEDTA], $30^{\circ} \mathrm{C}$ & [HEDTA], $25^{\circ} \mathrm{C}$ \\
\hline 0.00003 & 1.756 & 1.798 & 1.740 & 1.744 \\
\hline 0.001 & 1.748 & 1.753 & 1.769 & 1.772 \\
\hline 0.01 & 1.767 & 1.724 & 1.774 & 1.792 \\
\hline 0.1 & 1.742 & 1.720 & 1.679 & 1.739 \\
\hline 0.5 & 1.745 & 1.708 & 1.710 & 1.736 \\
\hline 1 & 1.643 & 1.619 & 1.602 & 1.669 \\
\hline \multirow[t]{2}{*}{2} & 1.483 & 1.470 & 1.469 & 1.477 \\
\hline & {$\left[\mathrm{NaNO}_{3}\right], 50^{\circ} \mathrm{C}$} & {$\left[\mathrm{NaNO}_{3}\right], 40^{\circ} \mathrm{C}$} & {$\left[\mathrm{NaNO}_{3}\right], 30^{\circ} \mathrm{C}$} & {$\left[\mathrm{NaNO}_{3}\right], 25^{\circ} \mathrm{C}$} \\
\hline 0.00003 & 3.277 & 3.376 & 3.228 & 3.212 \\
\hline 0.001 & 3.529 & 3.375 & 3.371 & 3.279 \\
\hline 0.01 & 3.493 & 3.329 & 3.438 & 3.281 \\
\hline 0.1 & 3.436 & 3.284 & 3.364 & 3.399 \\
\hline 0.5 & 3.543 & 3.386 & 3.480 & 3.479 \\
\hline 1 & 3.609 & 3.406 & 3.600 & 3.600 \\
\hline \multirow[t]{2}{*}{2} & 4.000 & 4.000 & 4.000 & 4.000 \\
\hline & {$\left[\mathrm{NaNO}_{2}\right], 50^{\circ} \mathrm{C}$} & {$\left[\mathrm{NaNO}_{2}\right], 40^{\circ} \mathrm{C}$} & {$\left[\mathrm{NaNO}_{2}\right], 30^{\circ} \mathrm{C}$} & {$\left[\mathrm{NaNO}_{2}\right], 25^{\circ} \mathrm{C}$} \\
\hline 0.00003 & 0.795 & 0.819 & 0.783 & 0.779 \\
\hline 0.001 & 0.856 & 0.819 & 0.817 & 0.795 \\
\hline 0.01 & 0.847 & 0.807 & 0.834 & 0.796 \\
\hline 0.1 & 0.833 & 0.796 & 0.816 & 0.824 \\
\hline 0.5 & 0.859 & 0.821 & 0.844 & 0.844 \\
\hline 1 & 0.875 & 0.826 & 0.873 & 0.873 \\
\hline \multirow[t]{2}{*}{2} & 0.970 & 0.970 & 0.970 & 0.970 \\
\hline & {$\left[\mathrm{NaOH}, 50^{\circ} \mathrm{C}\right.$} & {$[\mathrm{NaOH}], 40^{\circ} \mathrm{C}$} & {$[\mathrm{NaOH}], 30^{\circ} \mathrm{C}$} & {$[\mathrm{NaOH}], 25^{\circ} \mathrm{C}$} \\
\hline 0.00003 & $2.46 \mathrm{E}-05$ & $2.07 \mathrm{E}-05$ & $1.67 \mathrm{E}-05$ & $1.34 \mathrm{E}-05$ \\
\hline 0.001 & 8.82E-04 & 7.44E-04 & $6.27 \mathrm{E}-04$ & $5.14 \mathrm{E}-04$ \\
\hline 0.01 & 8.73E-03 & $7.27 \mathrm{E}-03$ & $6.25 \mathrm{E}-03$ & 5.12E-03 \\
\hline 0.1 & $8.59 \mathrm{E}-02$ & $7.05 \mathrm{E}-02$ & $5.93 \mathrm{E}-02$ & $5.04 \mathrm{E}-02$ \\
\hline 0.5 & $4.43 \mathrm{E}-01$ & 3.75E-01 & $3.26 \mathrm{E}-01$ & $2.84 \mathrm{E}-01$ \\
\hline 1 & $9.02 \mathrm{E}-01$ & $7.68 \mathrm{E}-01$ & $6.92 \mathrm{E}-01$ & $6.22 \mathrm{E}-01$ \\
\hline 2 & $2.00 \mathrm{E}+00$ & $2.00 \mathrm{E}+00$ & $2.00 \mathrm{E}+00$ & $2.00 \mathrm{E}+00$ \\
\hline
\end{tabular}


WHC-EP-0899-1

\begin{tabular}{|c|c|c|c|c|}
\hline \multirow{2}{*}{$\begin{array}{l}\text { Initial } \\
\text { [NaOH }\end{array}$} & \multicolumn{4}{|c|}{ EQUILIBRIUM SOLUBILITIES } \\
\hline & [HEDTA],50 ${ }^{\circ} \mathrm{C}$ & [HEDTA, $40^{\circ} \mathrm{C}$ & [HEDTA], $30^{\circ} \mathrm{C}$ & [HEDTA], $25^{\circ} \mathrm{C}$ \\
\hline 0.1 & 1.167 & 1.146 & 1.170 & 1.187 \\
\hline 0.5 & 1.187 & 1.149 & 1.162 & 1.168 \\
\hline 1 & 1.159 & 1.153 & 1.165 & 1.170 \\
\hline \multirow[t]{2}{*}{2} & 1.091 & 1.095 & 1.106 & 1.093 \\
\hline & [NaNO3], $50^{\circ} \mathrm{C}$ & {$[\mathrm{NaNO3}], 40^{\circ} \mathrm{C}$} & {$[\mathrm{NaNO}], 30^{\circ} \mathrm{C}$} & {$[\mathrm{NaNO} 3], 25^{\circ} \mathrm{C}$} \\
\hline 0.1 & 4.516 & 4.429 & 3.894 & 3.647 \\
\hline 0.5 & 4.509 & 4.343 & 3.785 & 3.566 \\
\hline 1 & 4.641 & 4.177 & 3.727 & 3.455 \\
\hline \multirow[t]{2}{*}{2} & 4.155 & 4.053 & 3.536 & 3.295 \\
\hline & {$[\mathrm{NaNO} 2], 50^{\circ} \mathrm{C}$} & [NaNO2], $40^{\circ} \mathrm{C}$ & INaNO2 $1,30^{\circ} \mathrm{C}$ & {$[\mathrm{NaNO} 2], 25^{\circ} \mathrm{C}$} \\
\hline 0.1 & 1.097 & 1.104 & 1.099 & 1.100 \\
\hline 0.5 & 1.084 & 1.077 & 1.075 & 1.083 \\
\hline 1 & 1.035 & 1.033 & 1.066 & 1.063 \\
\hline \multirow[t]{2}{*}{2} & 0.996 & 1.015 & 1.030 & 1.028 \\
\hline & {$[\mathrm{NaOH}], 50^{\circ} \mathrm{C}$} & {$\left[\mathrm{NaOH}, 40^{\circ} \mathrm{C}\right.$} & {$[\mathrm{NaOH}], 30^{\circ} \mathrm{C}$} & (NaOH $], 25^{\circ} \mathrm{C}$ \\
\hline 0.1 & 0.055 & 0.055 & 0.055 & 0.055 \\
\hline 0.5 & 0.281 & 0.279 & 0.278 & 0.281 \\
\hline 1 & 0.554 & 0.552 & 0.570 & 0.569 \\
\hline 2 & 1.151 & 1.173 & 1.190 & 1.189 \\
\hline
\end{tabular}


WHC-EP-0899-1

Butyrate Solubilities

(Molar Concentrations)

\begin{tabular}{|c|c|c|c|c|}
\hline \multirow{2}{*}{$\begin{array}{c}\text { Initial } \\
{[\mathrm{NaOH}]}\end{array}$} & \multicolumn{4}{|c|}{ EQUILIBRIUM SOLUBLITIES } \\
\hline & $B \mathrm{BUT}, 50^{\circ} \mathrm{C}$ & $B B U T, 60^{\circ} \mathrm{C}$ & {$[B U T], 30^{\circ} \mathrm{C}$} & {$[B U T], 25^{\circ} \mathrm{C}$} \\
\hline 0.00003 & 3.793 & 3.809 & 3.922 & 3.861 \\
\hline 0.001 & 3.799 & 3.945 & 3.988 & 3.779 \\
\hline 0.01 & 3.748 & 3.926 & 3.945 & 3.869 \\
\hline 0.1 & 3.720 & 3.859 & 3.970 & 3.887 \\
\hline 0.5 & 3.651 & 3.730 & 3.770 & 3.760 \\
\hline 1 & 3.202 & 3.257 & 3.314 & 3.359 \\
\hline \multirow[t]{2}{*}{2} & 2.704 & 2.606 & 2.660 & 2.719 \\
\hline & (NaNO3], $50^{\circ} \mathrm{C}$ & [NaNO3], $40^{\circ} \mathrm{C}$ & INaNO3 $/, 30^{\circ} \mathrm{C}$ & {$\left[\mathrm{NaNO3}, 25^{\circ} \mathrm{C}\right.$} \\
\hline 0.00003 & 2.314 & 2.267 & 1.913 & 2.060 \\
\hline 0.001 & 2.263 & 2.217 & 1.917 & 1.980 \\
\hline 0.01 & 2.527 & 2.247 & 1.930 & 1.970 \\
\hline 0.1 & 2.290 & 2.203 & 1.960 & 1.843 \\
\hline 0.5 & 2.187 & 2.243 & 2.000 & 1.825 \\
\hline 1 & 2.537 & 2.503 & 2.240 & 2.000 \\
\hline \multirow[t]{2}{*}{2} & 2.773 & 2.780 & 2.497 & 2.233 \\
\hline & {$[\mathrm{NaNO} 2], 50^{\circ} \mathrm{C}$} & [NaNO2], $40^{\circ} \mathrm{C}$ & [NaNO2], $30^{\circ} \mathrm{C}$ & INaNO2l, $25^{\circ} \mathrm{C}$ \\
\hline 0.00003 & 0.552 & 0.571 & 0.580 & 0.675 \\
\hline 0.001 & 0.522 & 0.553 & 0.586 & 0.621 \\
\hline 0.01 & 0.560 & 0.599 & 0.579 & 0.613 \\
\hline 0.1 & 0.546 & 0.579 & 0.588 & 0.589 \\
\hline 0.5 & 0.520 & 0.561 & 0.572 & 0.569 \\
\hline 1 & 0.610 & 0.633 & 0.646 & 0.635 \\
\hline \multirow[t]{2}{*}{2} & 0.690 & 0.709 & 0.706 & 0.709 \\
\hline & {$[\mathrm{NaOH}], 50^{\circ} \mathrm{C}$} & {$[\mathrm{NaOH}], 40^{\circ} \mathrm{C}$} & {$[\mathrm{NaOH}], 30^{\circ} \mathrm{C}$} & {$[\mathrm{NaOH}], 25^{\circ} \mathrm{C}$} \\
\hline 0.00003 & $1.74 \mathrm{E}-05$ & $1.70 \mathrm{E}-05$ & $1.44 \mathrm{E}-05$ & $1.55 \mathrm{E}-05$ \\
\hline 0.001 & $5.66 \mathrm{E}-04$ & $5.54 \mathrm{E}-04$ & 4.79E-04 & $4.95 \mathrm{E}-04$ \\
\hline 0.01 & $6.32 \mathrm{E}-03$ & $5.62 \mathrm{E}-03$ & $4.83 \mathrm{E}-03$ & 4.93E-03 \\
\hline 0.1 & $5.73 \mathrm{E}-02$ & $5.51 \mathrm{E}-02$ & $4.90 \mathrm{E}-02$ & $4.61 \mathrm{E}-02$ \\
\hline 0.5 & 2.73E-01 & $2.80 \mathrm{E}-01$ & $2.50 \mathrm{E}-01$ & $2.28 \mathrm{E}-01$ \\
\hline 1 & $6.34 \mathrm{E}-01$ & $6.26 \mathrm{E}-01$ & $5.60 \mathrm{E}-01$ & $5.00 \mathrm{E}-01$ \\
\hline 2 & $1.39 \mathrm{E}+00$ & $1.39 \mathrm{E}+00$ & $1.25 \mathrm{E}+00$ & $1.12 \mathrm{E}+00$ \\
\hline
\end{tabular}


WHC-EP-0899-1

Butyrate Solubilities In Sat NaNO3

Solution

\begin{tabular}{|c|c|c|c|c|}
\hline Initial & & EQULLIBRIUM & LUBLITIES & \\
\hline$[\mathrm{NaOH}]$ & [BUT],50 ${ }^{\circ} \mathrm{C}$ & BUTT, $40^{\circ} \mathrm{C}$ & {$[B U T], 30^{\circ} \mathrm{C}$} & [BUT], $25^{\circ} \mathrm{C}$ \\
\hline 0.1 & 3.113 & 3.213 & 3.366 & 3.450 \\
\hline 0.5 & 2.875 & 3.061 & 3.176 & 3.268 \\
\hline 1 & 2.601 & 2.830 & 3.013 & 3.072 \\
\hline 2 & 2.215 & 2.267 & 2.467 & 2.596 \\
\hline & [NaNO3], $50{ }^{\circ} \mathrm{C}$ & [NaNO3], $40^{\circ} \mathrm{C}$ & {$[\mathrm{NaNO} 3], 30^{\circ} \mathrm{C}$} & {$[\mathrm{NaNO}], 25^{\circ} \mathrm{C}$} \\
\hline 0.1 & 3.538 & 2.976 & 2.652 & 2.407 \\
\hline 0.5 & 3.619 & 3.078 & 2.686 & 2.225 \\
\hline 1 & 3.929 & 3.258 & 2.783 & 2.484 \\
\hline 2 & 3.963 & 3.403 & 2.317 & 2.520 \\
\hline & [NaNO2], $50^{\circ} \mathrm{C}$ & {$[\mathrm{NaNO} 2], 40^{\circ} \mathrm{C}$} & {$[\mathrm{NaNO} 2], 30^{\circ} \mathrm{C}$} & [NaNO2], $25{ }^{\circ} \mathrm{C}$ \\
\hline 0.1 & 1.175 & 1.201 & 1.276 & 1.264 \\
\hline 0.5 & 1.163 & 1.199 & 1.269 & 1.138 \\
\hline 1 & 1.208 & 1.223 & 1.275 & 1.243 \\
\hline 2 & 1.145 & 1.168 & 1.204 & 1.161 \\
\hline & {$[\mathrm{NaOH}], 50^{\circ} \mathrm{C}$} & {$[\mathrm{NaOH}], 40^{\circ} \mathrm{C}$} & {$[\mathrm{NaOH}], 30^{\circ} \mathrm{C}$} & {$[\mathrm{NaOH}], 25^{\circ} \mathrm{C}$} \\
\hline 0.1 & 0.059 & 0.060 & 0.064 & 0.064 \\
\hline 0.5 & 0.301 & 0.311 & 0.329 & 0.295 \\
\hline 1 & 0.646 & 0.654 & 0.682 & 0.665 \\
\hline 2 & 1.323 & 1.351 & 1.392 & 1.342 \\
\hline
\end{tabular}


THIS PAGE INTENTTONALLY

I.EFY BLANK 
WHC-EP-0899-1

\begin{abstract}
APPENDIX B
DENSITIES OF SIMULATED SUPERNATE

SOLUTIONS SATURATED WTTH ORGANIC SALTS

AND CRYSTALLINE SODIUM NITRATE
\end{abstract}

B-1 
WHC-EP-0899-1

Densities, $\mathrm{g} / \mathrm{mL}$

\begin{tabular}{|c|c|c|c|c|c|}
\hline \multirow[b]{2}{*}{ Organic Salt } & \multirow{2}{*}{$\begin{array}{c}\text { Initial } \\
{[\mathrm{NaOH}]}\end{array}$} & \multicolumn{4}{|c|}{ Temperature, ${ }^{\circ} \mathrm{C}$} \\
\hline & & 25 & 30 & 40 & 50 \\
\hline \multirow[t]{4}{*}{ Acetate } & 0.1 & 1.355 & 1.353 & 1.362 & 1.390 \\
\hline & 0.5 & 1.354 & 1.352 & 1.373 & 1.383 \\
\hline & 1 & 1.357 & 1.354 & 1.370 & 1.391 \\
\hline & 2 & 1.363 & 1.365 & 1.379 & 1.391 \\
\hline \multirow[t]{4}{*}{ Butyrate } & 0.1 & 1.242 & 1.276 & 1.298 & 1.304 \\
\hline & 0.5 & 1.244 & 1.280 & 1.305 & 1.310 \\
\hline & 1 & 1.275 & 1.289 & 1.254 & 1.319 \\
\hline & 2 & 1.275 & 1.304 & 1.281 & 1.337 \\
\hline \multirow[t]{4}{*}{ Caproate } & 0.1 & 1.362 & 1.392 & 1.404 & 1.417 \\
\hline & 0.5 & 1.356 & 1.391 & 1.407 & 1.431 \\
\hline & 1 & 1.357 & 1.394 & 1.406 & 1.437 \\
\hline & 2 & 1.381 & 1.389 & 1.389 & 1.414 \\
\hline \multirow[t]{4}{*}{ Citrate } & 0.1 & 1.423 & 1.432 & 1.439 & 1.459 \\
\hline & 0.5 & 1.388 & 1.418 & 1.439 & 1.454 \\
\hline & 1 & 1.421 & 1.419 & 1.437 & 1.453 \\
\hline & 2 & 1.404 & 1.410 & 1.422 & 1.450 \\
\hline \multirow[t]{4}{*}{ EDTA } & 0.1 & 1.419 & 1.434 & 1.443 & 1.463 \\
\hline & 0.5 & 1.421 & 1.435 & 1.445 & 1.465 \\
\hline & 1 & 1.427 & 1.425 & 1.441 & 1.460 \\
\hline & 2 & 1.456 & 1.423 & 1.444 & 1.449 \\
\hline \multirow[t]{4}{*}{ Formate } & 0.1 & 1.477 & 1.489 & 1.497 & 1.480 \\
\hline & 0.5 & 1.474 & 1.468 & 1.488 & 1.523 \\
\hline & 1 & 1.469 & 1.459 & 1.492 & 1.487 \\
\hline & 2 & 1.463 & 1.469 & 1.480 & 1.470 \\
\hline \multirow[t]{4}{*}{ Glycolate } & 0.1 & 1.443 & 1.449 & 1.469 & 1.480 \\
\hline & 0.5 & 1.443 & 1.455 & 1.470 & 1.406 \\
\hline & 1 & 1.437 & 1.455 & 1.466 & 1.479 \\
\hline & 2 & 1.411 & 1.453 & 1.466 & 1.473 \\
\hline \multirow[t]{4}{*}{ HEDTA } & 0.1 & 1.400 & 1.411 & 1.422 & 1.430 \\
\hline & 0.5 & 1.401 & 1.410 & 1.423 & 1.513 \\
\hline & 1 & 1.407 & 1.410 & 1.422 & 1.433 \\
\hline & 2 & 1.388 & 1.407 & 1.426 & 1.433 \\
\hline \multirow[t]{4}{*}{ Laurate } & 0.1 & 1.403 & 1.404 & 1.420 & 1.444 \\
\hline & 0.5 & 1.404 & 1.432 & 1.417 & 1.432 \\
\hline & 1 & 1.396 & 1.403 & 1.378 & 1.443 \\
\hline & 2 & 1.386 & 1.393 & 1.370 & 1.431 \\
\hline \multirow[t]{4}{*}{$N T A$} & 0.1 & 1.441 & 1.449 & 1.454 & 1.475 \\
\hline & 0.5 & 1.415 & 1.476 & 1.454 & 1.473 \\
\hline & 1 & 1.425 & 1.439 & 1.454 & 1.468 \\
\hline & 2 & 1.420 & 1.424 & 1.447 & 1.449 \\
\hline
\end{tabular}

B-2 
WHC-EP-0899-1

Densities, $g / m L$

\begin{tabular}{|cccccc|}
\hline & Initial & \multicolumn{4}{c|}{ Temperature, ${ }^{\circ} \mathrm{C}$} \\
Organic Salt & {$[$ NaOH $]$} & 25 & 30 & $\mathbf{4 0}$ & 50 \\
\hline Oxalate & 0.1 & 1.402 & 1.394 & 1.419 & 1.439 \\
\cline { 1 - 7 } & 0.5 & 1.385 & 1.389 & 1.411 & 1.428 \\
& 1 & 1.408 & 1.386 & 1.375 & 1.437 \\
\hline Palmitate & 2 & 1.386 & 1.386 & 1.408 & 1.417 \\
\hline & 0.1 & 1.387 & 1.393 & 1.409 & 1.437 \\
& 0.5 & 1.379 & 1.392 & 1.409 & 1.431 \\
\hline Succinate & 1 & 1.383 & 1.388 & 1.390 & 1.434 \\
& 2 & 1.387 & 1.386 & 1.369 & 1.427 \\
\hline & 0.1 & 1.395 & 1.397 & 1.413 & 1.435 \\
& 0.5 & 1.388 & 1.434 & 1.411 & 1.439 \\
& 1 & 1.390 & 1.395 & 1.375 & 1.435 \\
& 2 & 1.403 & 1.393 & 1.408 & 1.436 \\
\hline
\end{tabular}


TH

L.E BLANK 


\section{DISTRIBUTION}

\section{Number of copies}

\section{OFFSITE}

6

\section{U.S. Department of Energy}

EM-38, Trevion II

12800 Middlebrook Road

Germantown, MD 20874

Harry Calley

Maureen Hunemuller

Ken Lang (4)

2

U.S. Department of Energy

Forrestal Building

1000 Independence Avenue SW

Washington, DC 20585

Shirley Campbell, EH-71

John Kaysak, EM-25

1

David O. Campbell

102 Windham Road

Oak Ridge, TN 37830

1

Billy C. Hudson

202 Northridge Court

Lindsborg, KA 67456

1

Thomas S. Kress

102-B Newridge Road

Oak Ridge, TN 37839

1

Thomas E. Larson

2711 Walnut Street

Los Alamos, NM 87544

2

Fauske and Associates. Inc. 16W070 W. 83rd St.

Burr Ridge, IL 60521

Michael Epstein

Hans K. Fauske 


\section{DISTRIBUTION (Continued)}

\section{Number of copies}

\section{OFFSITE}

1

G \& P Consulting, Inc. 3640 Ballard Road

Dallas, OR 97338

Arlin K. Postma

Los Alamos National Laboratory

P.O. Box 1663

Los Alamos, NM 87545

Steve F. Agnew

1

MIT/Department of Nuclear Engineering

77 Massachusetts Ave.

Room 24-102

Cambridge, MA 02139

Mujid S. Kazimi

Nuclear Consulting Services, Inc.

P.O. Box 29151

Columbus, $\mathrm{OH} \quad 43229-0151$

\section{J. Louis Kovach}

1

Oak Ridge National Laboratory

Charles W. Forsberg

P.O. Box 2008

MS-6495

Oak Ridge, TN 37831-6495

Sandia National Laboratories

P.O. Box 5800

Albuquerque, NM 87185

Dana A. Powers, MS-0744

Scott E. Slezak, MS-0741 


\section{DISTRIBUTION (Continued)}

Number of copies

\section{OFFSITE}

1

1

\section{ONSITE}

8

1
State of Washington - Department of Ecology

Robert C. King

P. O. Box 47600

Olympia, WA $98504-7600$

Alex B. Stone

1315 W. 4th Avenue

Kennewick, WA 99336

S7-54

S. O. Branch

S7-54

W. F. Hendrickson

S7-54

D. H. Irby

A. G. Krasopoulos

A4-81

D. D. Wodrich

S7-50

Public Reading Room

H2-53

RL Docket File (2)

B1-17

\section{MACTEC}

M. H. Campbell

\section{Pacific Northwest National Laboratory}

J. W. Brothers

S. A. Bryan

P7-25

L. L. Burger

P7-25

D. M. Camaioni

K2-38

J. A. Campbell

P8-08

C. D. Carlson

P7-25

R. T. Hallen

P8-38

M. A. Lilga

P8-38

L. R. Pederson

K2-44

R. D. Scheele

P7-25 


\section{DISTRIBUTION (Continued)}

Westinghouse Hanford Company

H. Babad

S7-14

G. S. Barney (10)

T5-12

D. B. Bechtold

T6-09

D. R. Bratzel

S7-14

R. J. Cash

S7-14

T. D. Cooper

T5-12

J. A. Compton

T5-12

C. H. Delegard

T6-09

J. M. Grigsby

H4-62

D. L. Herting

T6-09

B. E. Hey

J. R. Jewett

T6-09

G. D. Johnson

T6-09

S. A. Jones

S7-15

N. W. Kirch

T5-12

M. L. Klem

R2-11

H5-27

E. J. Kosiancic

T6-16

J. E. Meacham (2)

S7-14

J. C. Person

T6-09

G. W. Reddick

H5-49

D. A. Reynolds

R2-11

J. P. Sloughter

T6-07

C. S. Sutter

T5-12

E. C. Vogt

T5-50

A. B. Webb

H4-65

W. I. Winters

T6-50

Central Files

A3-88

Correspondence Processing

A3-01

DPC

A3-94

EDMC

H6-08 